\title{
LIQUID PERFLUOROCHEMICALS AS FLEXIBLE AND EFFICIENT GAS CARRIERS APPLIED IN BIOPROCESS ENGINEERING: AN UPDATED OVERVIEW AND FUTURE PROSPECTS
}

\author{
Maciej Pilarek* \\ Warsaw University of Technology, Faculty of Chemical and Process Engineering, \\ ul. Waryńskiego 1, 00-645 Warsaw, Poland
}

\begin{abstract}
Fully synthetic, biochemically inert and water-immiscible liquid perfluorochemicals (PFCs) are recognised as flexible liquid carriers/scavengers of gaseous compounds (respiratory gases mainly, i.e. $\mathrm{O}_{2}$ and $\mathrm{CO}_{2}$ ) and increasingly applied in bioprocess engineering. A range of unmatched physicochemical properties of liquid PFCs, i.e. outstanding chemo- and thermostability, extremely low surface tension, simultaneous hydro- and lipophobicity, which result from carbon chain substitution with fluorine atoms (the most electronegative chemical element) and the presence of intramolecular $\mathrm{C}-\mathrm{F}$ bonds (the strongest single bond known in organic chemistry) have been described in detail. Exceptional propensity to solubility of respiratory gases in liquid perfluorinated compounds has been widely discussed. Advantages and disadvantages of bioprocess applications of liquid PFCs in the form of a pure PFC as well as in an emulsified form have been pointed out. A liquid PFC-mediated mass transfer intensification in various types of microbial, plant cell and animal cell culture systems: from miniaturised microlitre-scale cultures, via biomaterial-based scaffolds containing culture systems, to litre-scale bioreactors, has been reviewed and elaborated on bearing in mind the benefits of bioprocesses.
\end{abstract}

Keywords: liquid perfluorochemical (fluorocarbon), liquid gas carrier, solubility, cell/tissue culture, hybrid culture system

\section{INTRODUCTION}

The key function of a properly developed culture system (i.e. bioreactor) is to provide a designed and properly controlled environment as well as a predicted concentration of nutrients and culture medium components (dissolved oxygen, mainly) sufficient to achieve optimal growth in bioprocesses focused on cell cultures. The level of dissolved oxygen in the culture medium is the result of a balance between its consumption rate in the cells suspended in the broth (i.e. the oxygen uptake rate), and the rate of oxygen transfer from the gas carrier (sparged air bubbles, typically) to the liquid phase (i.e. oxygen transfer rate). Up to date, a considerable amount of extensive literature focused on mass transfer in variously agitated gas - liquid contacting culture systems has been reported, discussed or reviewed (Galaction et al., 2004; Garcia-Ochoa et al., 2010; Gogate et al., 2000; Martin et al., 2010; Suresh et al. 2009). A sufficient level of oxygen dissolved in the culture medium must be provided as a mandatory issue in every aerobic bioprocess because the concentration of dissolved oxygen becomes the keyfactor governing the metabolic pathway complexity in all kinds of aerobic cells (i.e. many microbial, all plant as well as insect, mammalian, and human cells) which are cultured in vitro. This is due to the fact 
that in every aerobic metabolism process the energy is generated by substrate (organic carbon source, mainly) oxidation.

Therefore, from the bioprocess point of view, oxygen is often the limiting nutrient in microbial cultures, as well as in plant, insect or animal cell/tissue successful growth in vitro. This results directly from the poor solubility of oxygen in water (which is the basic solvent of nutrients in all culture media) which is finally responsible for insufficient transfer of oxygen from gas phase through aqueous medium to cell surface. The oxygen concentration in a typical aqueous-phase culture medium is limited to ca. $0.2 \mathrm{mM}$ (i.e. twice its solubility in pure water) when atmospheric air is used for aeration. Based on equimolar intracellular biochemical reactions of monosaccharides oxidation, oxygen is typically consumed at approximately the same rate as glucose, but oxygen solubility is much lower than the availability of glucose in a typical culture medium (i.e., ca. $20-200 \mathrm{mM}$ depending on type of cultured cells) (Centis and Vermette, 2009; Martin and Vermette, 2005).

At the same time, significant carbon dioxide accumulation in culture medium can exist, especially at high cell density conditions observed in a range of bioprocess applications of microbes (bacteria, yeasts, fungi, as well as microalgae), in monolayered mammalian cell cultures and especially during in vitro development of 3-D aggregated mammalian and human cell constructs or implants where the value of the cell number to medium volume ratio is much higher than in culture systems containing suspended cells. It results in a significant acidification of culture medium and in increase of its osmolality due to the dissolution of bicarbonate anions (Glazyrina et al., 2012; Zhu et al., 2005).

Difficulties, both in achieving a sufficient level of dissolved oxygen and in reducing a culture system carbon dioxide level to the physiological range motivate investigators to continue search for bioprocess solutions which intensify the mass transfer between the elements of a culture system (i.e. oxygenation agent, culture medium and continuously metabolising cells). Water-immiscible liquid gas carriers such as saturated hydrocarbons (Lai et al., 2012; Li et al., 2012; da Silva et al., 2006), oils (Dumont et al., 2006; Han et al., 2009), haemoglobin derivatives (Davey et al., 2003; Lowe et al., 2001) or perfluorinated compounds (Dumont et al., 2006; Menge et al., 2001; Ntwampe et al., 2010; Pilarek and Szewczyk, 2005) characterised by $\mathrm{O}_{2} / \mathrm{CO}_{2}$ solubility much higher than that in water, are alternatives to conventional aeration systems applied in bioreactors and other small (i.e. micro- and milliliter-) scale culture systems. Fully synthetic, biochemically inert and immiscible with aqueous phases, liquid perfluorochemicals (synonym: fluorocarbons; PFCs) are recognised as some of the most flexible liquid carriers/scavengers of gaseous compounds (respiratory gases mainly, i.e. $\mathrm{O}_{2}$ and $\mathrm{CO}_{2}$ ) in bioprocess engineering applications. Other types of liquid gas carriers may cause negative or even detrimental effects on cultured cells, e.g. hydrocarbons can be toxic and oils can be metabolised by cells (Menge et al., 2001; Pilarek and Szewczyk, 2008). Up to date, PFCs have been frequently applied in bioreactors, as well as small-scale or miniaturised culture systems of various types of cells, i.e. microorganisms, e.g. bacteria (Pilarek et al., 2011; Pilarek et al., 2013a), yeast (Pilarek and Szewczyk, 2008; Pilarek et al., 2006), fungi (Elibol, 2001) or microalgae (Hillig et al., 2013; Hillig et al., 2014), or plant cells (Davey et al. 2005; Lowe at al. 2003; Pilarek and Szewczyk 2008; Sykłowska-Baranek et al. 2014) as wells as animal (Douglas et al. 2014; Pilarek et al., 2013b; Pilarek et al., 2014; Rappaport, 2003; Shiba et al., 1998) to successfully obtain higher cell densities or to identify positive influence on metabolite excretion due to enhanced the mass transfer effects in culture systems, mainly.

The aim of this review is to widely outline and extensively discuss the application effects of liquid perfluorinated gas carriers in various types of microbial, plant cell and animal cell culture systems: from miniaturised microlitre-scale cultures, via biomaterial-based scaffolds containing culture systems, to litre-scale bioreactors. A range of unmatched physicochemical properties of liquid PFCs, i.e. chemoand thermostability, extremely low surface tension, simultaneous hydro- and lipophobicity, have been described in detail. Exceptional propensity to solubility of respiratory gases in liquid perfluorinated compounds has been widely discussed. The benefits of liquid PFC-mediated mass transfer intensification in bioprocesses have been also looked into. 


\section{CHARACTERISTIC AND PHYSICOCHEMICAL PROPERTIES OF PFCS}

PFCs are fluorine substituted analogues of saturated aliphatic hydrocarbons with linear, cyclic or polycyclic molecules. A loose but common definition of perfluorinated compounds encompasses highly fluorinated molecules containing also occasional hydrogen, oxygen, nitrogen atoms or halogens other than fluorine. The general empirical formula of acyclic PFCs fully substituted with fluorides $\left(C_{n} F_{2 n+2}\right)$ is corresponding to the general empirical formula of fully saturated acyclic alkanes $\left(\mathrm{C}_{n} \mathrm{H}_{n+2}\right)$ (Riess, 2001).

Liquid PFCs, as well as all perfluorinated materials, are totally synthetic compounds. PFCs are obtained by controlled fluorination (with elementary fluorine) of vaporised alkanes diluted with an auxiliary gaseous agent, e.g. nitrogen, helium, argon, or in a liquid phase, e.g. hydrogen fluoride, liquid PFCs, trichlorofluoromethane (i.e. R-11 freon), in the presence of metal fluorides as a catalyst (cobalt trifluoride or its complex salts, mainly) (Lewandowski et al., 2006; Sanford, 2003). Another way of PFC production is anode electrochemical fluorination and telomerisation of tetrafluoroethylene $\left(\mathrm{CF}_{2}=\mathrm{CF}_{2}\right)$ in the presence of adequate telogens (e.g. iodine, pentafluoride iodine). Especially telomerisation process has enabled liquid PFC (e.g. perflubron ${ }^{\circledR}$ ) production on a multi-ton scale in at least $99 \%$ purity (Riess and Krafft, 2006). Perfluorodecalin $\left(\mathrm{C}_{10} \mathrm{~F}_{18}\right.$; PFD) is actually produced in at least $98 \%$ purity as an equimolar mixture of cis-/trans- isomers by controlled fluorination of decalin $\left(\mathrm{C}_{10} \mathrm{H}_{18}\right)$ in the presence of $\mathrm{CoF}_{3}$ (Shine et al., 2005).

\subsection{Chemical characteristic}

The chemical structure of carbon chains substituted with fluorine atoms provides a range of unmatched physicochemical properties of PFCs. Fluorine atom is the most electronegative chemical element (electronegativity 3.98$)$ and its van der Waals radius $(1.47 \AA)$ is only slightly larger than the value for hydrogen atom (1.20 $\AA$ ) (Eaton and Smart, 1990; Kirsch, 2004) which results in the higher dipole moment of $\mathrm{C}-\mathrm{F}$ bond $(1.41 \mathrm{D})$ compared to $\mathrm{C}-\mathrm{H}$ bond $(0.40 \mathrm{D})$. Fluorine has a higher ionisation potential than hydrogen, just after the inert gases helium and neon. Another attribute of fluorine is lower polarisability than hydrogen - second only to neon. Such differences are the basic structural reasons for different physicochemical properties revealed by conventional hydrocarbons and their perfluorinated analogues. PFCs are recognised as compounds characterised by outstanding chemo- and thermostability (they were initially developed for handling extremely corrosive uranium fluorides), as well as biochemical inertness due to the presence of the intramolecular C-F bonds, the strongest single bond known in the whole organic chemistry with bond strength of ca. $485 \mathrm{~kJ} / \mathrm{mol}$ (as compared to ca. $425 \mathrm{~kJ} / \mathrm{mol}$ for C-H bonds) (Krafft and Riess, 2002). Such effects are additionally enhanced by dense electron sheath which coats the carbon chain in a PFC's molecule and results in its stiffness, as well as protection and repellency from attacking ligands higher than in hydrocarbon analogues (Eaton and Smart, 1990; Lowe 2001). The mean volumes of $-\mathrm{CF}_{2}-$ and $-\mathrm{CH}_{2}-$ groups are $38 \AA^{3}$ and $27 \AA^{3}$, respectively, while the difference in volumes of $-\mathrm{CF}_{3}$ and $-\mathrm{CH}_{3}$ groups (i.e. $92 \AA^{3}$ and $54 \AA^{3}$, respectively) is even more significant (Gruen, 1985; Riess, 2002a). Furthermore, structural features of stiff chains of linear PFCs allow them to adopt a helical conformation, rather than the usual planar "zig-zag" arrangement found in hydrocarbon chains, in order to minimise steric effects (Gomes and Gomes, 2007). Owing to their bioengineering applications, PFCs exhibit high resistance to heat sterilisation (e.g. by typical autoclaving at $121^{\circ} \mathrm{C}$ ) and long-time storage potential at room temperature. Fluorinated compounds can resist highly aggressive media, including strong mineral acids, alkalis and oxidants, even in high temperature. To give as an example, poly(tetrafluoroethylene), commonly known as Teflon ${ }^{\circledR}$ (PTFE), is one of the most inert organic materials known (Hondred et al., 2013). 


\subsection{Physical characteristic}

In contrast to the strength of intramolecular bonds, liquid PFCs are characterised by very low values of the van der Waals forces resulting in the lowest polarisability of fluoride substituents $\left(0.56 \times 10^{-24} \mathrm{~cm}^{3}\right)$ of all atoms (Kirsch, 2004). A tight packing of highly electronegative fluorine atoms in liquid PFCs causes very low intermolecular cohesiveness which results in the extremely low surface tension (the lowest surface tension of any organic liquids), and therefore PFCs wet almost any surface (Lewandowski et al. 2006). The PFC-water surface tension is below $6 \times 10^{-2} \mathrm{~N} / \mathrm{m}$ (Riess, 2005). Low cohesiveness also causes very weak dispersion forces between PFC molecules and it is the reason for the simultaneous hydro- and lipophobicity of liquid PFCs (Kirsch, 2004; Krafft and Riess, 2007). Therefore they exhibit maximum water solubility level around $10^{-8}-10^{-9}$ mole which is the lowest water solubility of all liquids (Ruiz-Cabello et al., 2011). Some physicochemical properties of PFD and 1-bromoperfluorooctane $\left(\mathrm{C}_{8} \mathrm{~F}_{17} \mathrm{Br}\right.$; perflubron $\left.{ }^{\circledR}\right)$, which are definitely the most frequently applied liquid PFCs as liquid gas carriers on bioprocess and biomedical engineering field, are compared in Table 1.

Table 1. Comparison of some physicochemical properties of PFD and perflubron ${ }^{\circledR}$

\begin{tabular}{|l|l|l|l|}
\hline \multicolumn{1}{|c|}{ property } & \multicolumn{1}{c|}{ water } & \multicolumn{1}{c|}{ PFD $^{*}$} & \multicolumn{1}{c|}{ perflubron ${ }^{\circledR}$} \\
\hline molecular formula & $\mathrm{H}_{2} \mathrm{O}$ & $\mathrm{C}_{10} \mathrm{~F}_{18}$ & $\mathrm{C}_{8} \mathrm{~F}_{17} \mathrm{Br}$ \\
\hline molecular weight $\left[\mathrm{g} \mathrm{mol}^{-1}\right]$ & 18 & 462 & 499 \\
\hline melting point $\left[{ }^{\circ} \mathrm{C}\right]$ & 0 & 6 & -10 \\
\hline boiling point $\left[{ }^{\circ} \mathrm{C}\right]$ & 100 & 142 & 142 \\
\hline vapour pressure at $\left.37^{\circ} \mathrm{C}^{2} \mathrm{kPa}\right]$ & 6.27 & 1.87 & 1.40 \\
\hline kinematic viscosity $\left[\mathrm{m}^{2} \mathrm{~s}^{-1}\right]$ & $8.92 \times 10^{-7}$ & $2.90 \times 10^{-6}$ & $1.00 \times 10^{-6}$ \\
\hline interfacial tension toward water $\left[\mathrm{N} \mathrm{m}^{-1}\right]$ & - & $5.56 \times 10^{-2}$ & $5.50 \times 10^{-2}$ \\
\hline spreading coefficient on water $\left[\mathrm{N} \mathrm{m}^{-1}\right]$ & - & $-1.5 \times 10^{-3}$ & $+2.7 \times 10^{-3}$ \\
\hline solubility in water $\left[\mathrm{mol} \mathrm{dm}^{-3}\right]$ & - & $1 \times 10^{-8}$ & $5 \times 10^{-9}$ \\
\hline
\end{tabular}

* equimolar mixture of cis-/trans- isomers

The occurrence of large miscibility gaps in multi-phase solvent systems composed of hydrocarbons, aqueous media and liquid PFCs results in the development of a third liquid phase, named as "fluorous" vel "perfluorous", in addition to the "organic" and "aqueous" phases. The perfluorous phase is located at the bottom of the water/PFC system due to the relatively high density of liquid PFCs (about $\left.1.8-1.9 \cdot 10^{3} \mathrm{~kg} \mathrm{~m}^{-3}\right)$. Such unique immiscibility of liquid PFCs with other organic and aqueous phases is one of the main properties which promotes the spread of liquid PFCs applicability and range of patent submissions applied to their use in organic synthesis (e.g. US Patent 5463082. 31.10.1995; US Patent 6897331, 24.05.2005; US Patent 7404943. 29.07.2008), bioprocess engineering (e.g. EU Patent 0164813. 18.12.1985; EU Patent 2402433. 04.01.2012; PL Patent P-404726 16.07.2013), and on biomedical field (e.g. US Patent 4105798. 08.08.1978; US Patent 5531219. 02.07.1996; US Patent 20060278224. 22.03.2011). It is also important that liquid PFCs added to a reaction or culture system do not change the concentration of its components dissolved in aqueous phase.

\section{SOLUBILITY OF RESPIRATORY GASES IN LIQUID PFCS}

From the bioprocess engineering point of view, liquid PFCs have one special advantage over any other aqueous or organic compounds applied into culture systems - they exhibit an exceptional propensity to dissolve gases, including respiratory gases, i.e. oxygen and carbon dioxide. A very high oxygen carrying capacity $\left(\mathrm{O}_{2}\right.$ c.c. $)$ of liquid $\mathrm{PFCs}$ combined with their extreme oxidative decomposition 
strength make liquid PFCs an efficient oxygen carrier with very wide applicability in biomedical engineering field, as well as in bioprocess engineering. It is assumed that the gas absorption rate in liquid PFCs increases linearly with the partial pressure of a component in the gaseous phase, according to the Henry's Law, in contrast with sigmoidal dissociation curves for biochemical oxygen carriers, i.e. oxygen-binding globular proteins naturally occurring in animal blood (haemoglobin, $\mathrm{Hb}$ ) or muscle tissue (myoglobin, Mb) (Elliott, 2011; Kraft and Riess, 1998; Lowe, 2001; Wesseler et al., 1977). In general, the basic molecular difference between oxygen transfer by liquid PFCs and $\mathrm{Hb}$ is that PFCs passively dissolve and release gases without interacting with them, whereas $\mathrm{Hb}$ reversibly binds dioxygen molecules. Gas molecules occupy intermolecular spaces within the liquid phase of PFC (Lamy and Deby-Dupont, 2009; Lowe 2001; Riess 2001). A comparison of oxygen-carrying capacity of PFD and perflubron ${ }^{\circledR}$, i.e. two biomedically utilised perfluorinated oxygen carrier agents, with human blood plasma, $\mathrm{Hb}$ and $\mathrm{Mb}$ is presented in Fig. 1. Thus, at a given partial pressure of oxygen, $\mathrm{Hb}$ or $\mathrm{Mb}$ binds more $\mathrm{O}_{2}$ than can be dissolved in typical liquid PFCs. However oxygen solubility in liquid perfluorinated compounds (with a range of $35-44 \mathrm{mM}$ (Deschamps et al., 2007; Riess, 2006a) is approximately 20 times higher than the solubility of oxygen in water $(2.2 \mathrm{mM})$ at standard temperature and pressure. The solubility of carbon dioxide exceeds $200 \mathrm{mM}$ (Lowe, 2002; Riess, 2001). What is also valuable, gas solubility in liquid PFCs decreases in the following order (Lowe, 2001):

$$
\mathrm{CO}_{2} \gg \mathrm{O}_{2}>\mathrm{CO}>\mathrm{N}_{2}
$$

which makes them suitable in a range of bioprocess applications for oxygen delivery and removal of metabolically generated carbon dioxide from culture systems.

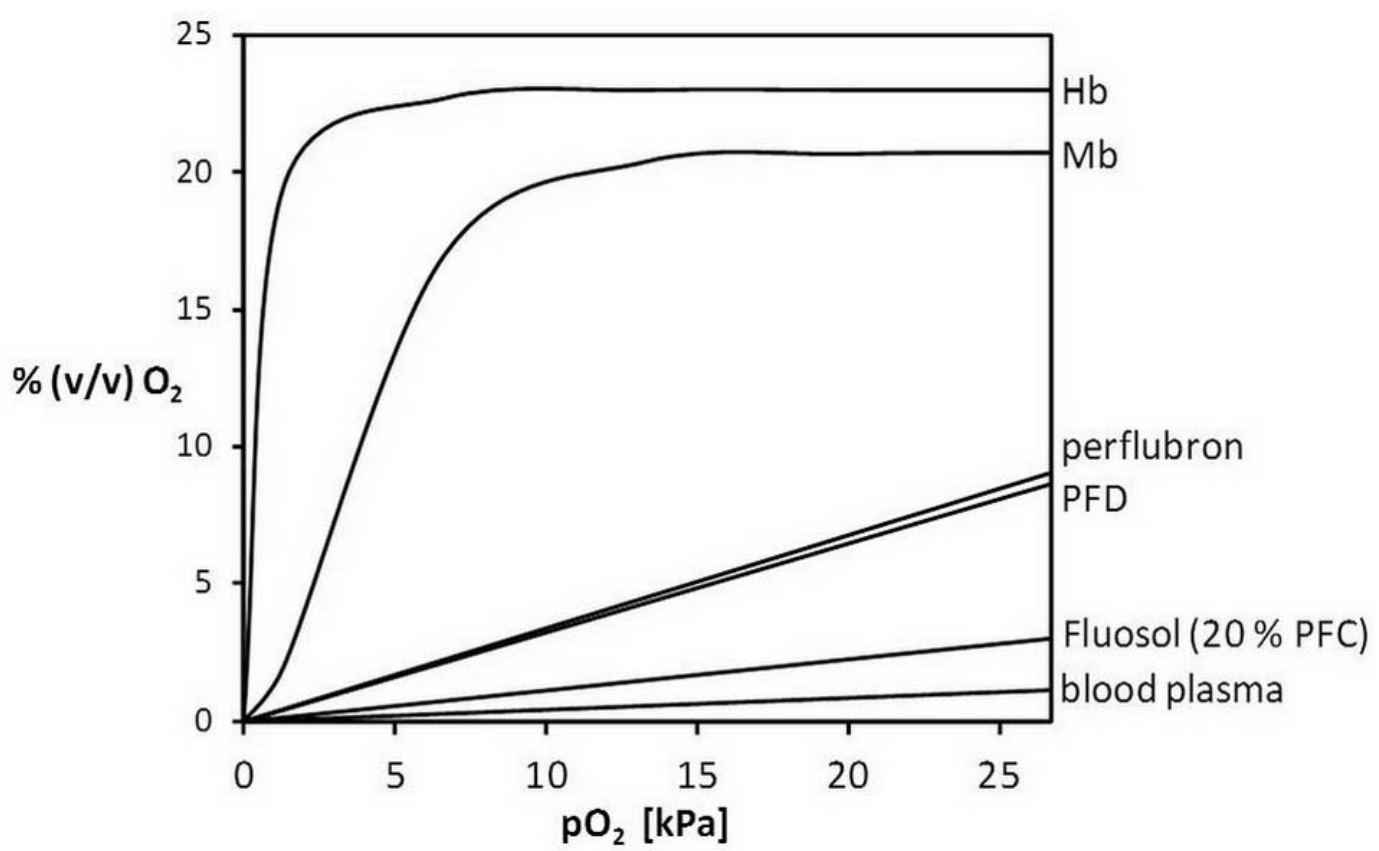

Fig. 1. Comparison of oxygen-carrying capacity of PFD, perflubron ${ }^{\circledR}$ and Fluosol-DA (as an example of biomedically utilised liquid PFC-based emulsion) with human blood plasma, $\mathrm{Hb}$ and $\mathrm{Mb}$ (based on Kirsch, 2004; Lowe 1999 and Riess, 2001)

Previously published data on the solubility of oxygen and carbon dioxide in PFD and perflubron ${ }^{\circledR}$ are listed in Table 2. In order to facilitate a comparison of the data, they were expressed (after conversion from the Ostwald coefficient $\left(L_{2,1}\right)$ if needed) as the Henry's Law constant $(H)$ defined as:

$$
p_{i}=H c_{i}
$$


Table 2. Solubility of oxygen and carbon dioxide in perfluorodecalin and 1-bromoperfluorooctane expressed as the Henry's law constant defined as in Eq. 2

\begin{tabular}{|c|c|c|c|c|c|}
\hline \multirow{2}{*}{ liquid PFC } & $\mathrm{O}_{2}$ & $\mathrm{CO}_{2}$ & \multirow{2}{*}{$\begin{array}{c}T \\
{[\mathrm{~K}]}\end{array}$} & \multirow{2}{*}{$\begin{array}{c}p \\
{[\mathrm{kPa}]}\end{array}$} & \multirow{2}{*}{ reference } \\
\hline & $\begin{array}{c}H \\
{\left[\mathrm{kPa} \mathrm{m}^{3} \mathrm{~mol}^{-1}\right]}\end{array}$ & $\begin{array}{c}H \\
{\left[\mathrm{kPa} \mathrm{m}^{3} \mathrm{~mol}^{-1}\right]}\end{array}$ & & & \\
\hline \multirow{5}{*}{$\begin{array}{l}\text { perfluorodecalin } \\
\left(\mathrm{C}_{10} \mathrm{~F}_{18} ; \mathrm{PFD}\right)\end{array}$} & $5.94-6,29$ & - & $288.6-311.4$ & $96.1-98.4$ & $\begin{array}{l}\text { Deschamps } \\
\text { et al., } 2007\end{array}$ \\
\hline & - & $1.29-1.72$ & $288.6-312.3$ & $95.0-97.2$ & $\begin{array}{c}\text { Costa Gomes } \\
\text { et al., } 2004\end{array}$ \\
\hline & $5.79-6.38$ & - & $288.3-312.2$ & 101.3 & Freire et al., 2004 \\
\hline & - & 0.820 & 293.1 & 101.3 & $\begin{array}{c}\text { Sobieszuk and } \\
\text { Pilarek, } 2012\end{array}$ \\
\hline & 2.85 & - & 293.1 & 101.3 & $\begin{array}{c}\text { Pilarek et al., } \\
2013 \mathrm{c}\end{array}$ \\
\hline \multirow{2}{*}{$\begin{array}{c}\text { 1-bromoperfluorooctane } \\
\left(\mathrm{C}_{8} \mathrm{~F}_{17} \mathrm{Br} ; \text { perflubron }^{\circledR}\right)\end{array}$} & $5.26-5.73$ & $1.17-1.55$ & $289.8-311.0$ & $93.5-97.7$ & $\begin{array}{l}\text { Deschamps } \\
\text { et al., } 2007\end{array}$ \\
\hline & $5.43-5.84$ & - & $289.2-316.5$ & $95.7-97.1$ & $\begin{array}{c}\text { Costa Gomes } \\
\text { et al., } 2004\end{array}$ \\
\hline
\end{tabular}

It should be emphasised that the data available in the open literature for the solubility of gases in liquid PFCs are still rather limited, with most data widely scattered. The incomplete quantitative characterisation of the used PFC samples or the imprecise descriptions of the employed experimental methods makes it difficult to compare most of previously published data. Moreover, most of the available data on the $\mathrm{O}_{2}$ and $\mathrm{CO}_{2}$ solubility in liquid PFCs refers to the values measured in only one temperature, e.g. 20 or $37^{\circ} \mathrm{C}$, as well as measured for perfluorinated compounds in an emulsified form.

\section{GAS CONCENTRATION DETERMINATION IN LIQUID PFCS}

It is not possible to directly measure the concentration of dissolved oxygen in liquid PFCs. The standard method using the Clark electrode is not applicable due to hydrophobicity of fluorinated phase. Therefore, it is necessary to apply indirect methods. Because of the relatively high costs of liquid PFCs, using a typical apparatus to determine the values of gas solubility, e.g. the laminar-jet (Pohorecki and Moniuk, 1988), is uneconomical and thus problematic. An isobaric saturation method was most frequently employed to quantitatively determine solubility of gases in liquid PFCs (Costa Gomes et al., 2004; Deschamps et al., 2007; Freire et al., 2004) expressed as the Ostwald coefficient $\left(L_{2,1}\right)$. Furthermore, a modified enzymatic method (Pilarek et al., 2013c), originally developed by Freire (2005) to determine the oxygen solubility in liquid PFCs-based emulsions, was successfully employed to determine oxygen concentration in microliter-scale samples of PFD, as well as volumetric gas-side mass transfer coefficient $\left(k_{p} a=0.051 \mathrm{~mol} \mathrm{~m}^{-3} \mathrm{~s}^{-1} \mathrm{kPa}^{-1}\right)$ and volumetric liquid-side mass transfer coefficient $\left(k_{L} a=3.63 \times 10^{-3} \mathrm{~s}^{-1}\right)$ for a PFD-oxygen/air two-phase system. The gas-liquid flow in a microchannel has been proposed by Sobieszuk and Pilarek (2012) for mass transfer investigations in $\mathrm{PFD} / \mathrm{CO}_{2}$ systems. The Henry's law constant has been determined based on the estimated values of the $\mathrm{CO}_{2}$ absorption rates in the applied microchannel device and using the correlation for mass transfer coefficient in the Taylor flow due to Yue et al. (2007). Such investigation was also the first report of the application of liquid PFC in a microreactor system in general. Summarising, all previously published data on oxygen solubility in PFD and perflubron seems to be consistent (see Table 2) and basically they are sufficient to approve biomedical application of liquid PFCs or to develop bioprocesses utilising liquid PFC-based carriers of respiratory gases. 


\section{LIQUID PFC-BASED EMULSIONS}

As insoluble in water, liquid PFCs can be converted to an emulsified form using different types and concentrations of a range of surfactants. The form of liquid PFC-based emulsions depends on the way of its bioengineering application. Two main lines of research are being actively pursued: (i) PFC-inwater emulsions for in vivo intravascular oxygen delivery (known as perfluorinated temporary blood substitutes) (Krafft et al., 2003; Riess, 2006b; Vasquez et al., 2013), as storage-media during organ transplantation procedures (Bezinover et al., 2014; Maillard et al., 2008; Terai et al., 2010), currently under development for treatment of traumatic brain and spinal cord injury (Spiess, 2009) as well as in decompression sickness therapy (Randsoe and Hyldegaard, 2009), and (ii) water-in-PFC reverse emulsions for pulmonary drug delivery (Courrier et al., 2004; Smoła et al., 2008), targeted emulsions for diagnosis and therapy (Kaufmann and Lindner, 2007; Lanza and Wickline, 2001; Martin and Dayton, 2013), as well as valuable research tool used in polymerisation technology (Chen et al., 2010; Zetterlund et al., 2008).

It should be emphasised that from the point of view of bioengineering, PFC-in-water emulsions (particle size of approximately $0.2 \mu \mathrm{m}$ ) have much greater importance for intravenous administration than the others. Nowadays, they are usually formulated as submicron, i.e. nano- or micro- PFC-in-water emulsions, preferably, to increase their stability (Maevsky and Ivanitsky, 2005; Riess, 2002b) and thus significantly smaller (10 to 100 times) than the size of erythrocytes. Not only smaller droplet size, but also significantly larger relative surface-to-volume ratio of PFC drops create favourable gas exchange conditions. Aside from adequate dispersion, homogeneity and reproducibility of small droplets of liquid PFC, formulation of emulsion with high applicability in bioengineering field requires a surfactant system and manufacturing procedures capable of ensuring stability, biocompatibility and possibility for heat-sterilisation. Poloxamers (e.g. Pluronics and Proxanols, mainly) and natural phospholipids (e.g. from egg yolk, mainly), which are commonly utilised in the formulation of pharmaceuticals, seem to be capable of meeting all of these requirements (Bouchemal, 2004; Kaufman, 1992; Riess and Krafft, 2006). The key idea in developing liquid PFCs-based emulsions is to apply them in vivo as intravenously injectable temporary blood substitutes. PFC-in-water emulsions intended for biomedical use are produced at concentrations ranging from $20 \%$ up to $120 \%$ weight/volume. Osmolarity of the suspending media is independent of liquid PFC concentration and is adjusted by the addition of tonicity agents (Cabrales and Intaglietta, 2013). Up to date, several emulsion systems based on a few liquid PFC agents have been commercially developed and they are generally in preclinical/clinical trials, as reported in Table 3.

Three main criteria to differentiate between $1^{\text {st }}$ and $2^{\text {nd }}$ generations of liquid PFC-based emulsions have been proposed by Kusnetzova (2003):

- concentration of liquid PFC agents in $2^{\text {nd }}$ generation emulsions is twice or even four times higher compared to $1^{\text {st }}$ generation,

- natural emulsifiers are ingredients of $2^{\text {nd }}$ generation emulsions,

- $2^{\text {nd }}$ generation emulsions can be stored in room temperature in contrast to $1^{\text {st }}$ generation emulsions that need to be frozen.

Simplifying, the $2^{\text {nd }}$ generation emulsions have been developed in order to overcome the difficulties in biomedical applications exhibited by the $1^{\text {st }}$ generation. They are supplied in an emulsified form and capable to withstand temperature variations during preparation and shipping (e.g. Oxycyte can be stored at $4^{\circ} \mathrm{C}$, with a shelf life of $18-24$ months). Liquid PFCs are used in an emulsified form in order to increase the interfacial exchange surface. Nevertheless, from the bioprocess point of view, most commercially developed liquid PFC-based emulsions are not fully applicable in culture systems containing living cells. The main reason is the content of non-perfluorinated additives which may influence negatively cells (e.g. phospholipids utilised as emulsifiers) or they may be metabolised (e.g. 
plant-origin additives, $\alpha$-tocopherol). They may negatively affect culture processes conducted in bioreactor systems (e.g. increased foaming caused by surfactants).

Table 3. Liquid PFC-based emulsions developed as injectable temporary blood substitutes

\begin{tabular}{|c|c|c|c|c|c|c|}
\hline generation & $\begin{array}{c}\text { product } \\
\text { (manufacturer, } \\
\text { country) }\end{array}$ & $\begin{array}{c}\mathrm{PFC} \\
{[\% \mathrm{w} / \mathrm{v}]}\end{array}$ & $\begin{array}{c}\text { surfactants } \\
{[\% \mathrm{w} / \mathrm{v}]}\end{array}$ & $\begin{array}{l}\text { additives } \\
\text { and buffer }\end{array}$ & $\begin{array}{c}O_{2} \text { c.c. } \\
{\left[\mathrm{cm}^{3} \mathrm{O}_{2} \mathrm{dm}^{-}\right.} \\
\left.{ }^{3} \mathrm{kPa}^{-1}\right]\end{array}$ & reference \\
\hline \multirow{3}{*}{$1^{\text {st }}$} & \begin{tabular}{|c|} 
Fluosol-DA \\
(Alpha \\
Therapeutic Corp., \\
US; previously: \\
Green Cross Corp., \\
JP) \\
\end{tabular} & $\begin{array}{c}14 \% \text { PFD } \\
6 \% \text { PFTPA }\end{array}$ & \begin{tabular}{|c|}
$2.7 \%$ Pluronic \\
F-68 \\
$0.4 \%$ EYP \\
$0.03 \%$ \\
potassium \\
oleate \\
\end{tabular} & $\begin{array}{c}\mathrm{NaCl}, \mathrm{KCl}, \\
\mathrm{MgCl}_{2}, \\
\mathrm{CaCl}_{2}, \\
\mathrm{Ca}\left(\mathrm{HCO}_{3}\right)_{2}, \\
\text { glycerol, } \\
\text { dextrose } \\
\end{array}$ & $0.06 \times 10^{-2}$ & $\begin{array}{l}\text { Mitsuno } \\
\text { et al., } 1982\end{array}$ \\
\hline & \begin{tabular}{|c|} 
Oxypherol \\
(Alpha \\
Therapeutic Corp., \\
US; previously: \\
Green Cross Corp., \\
JP)
\end{tabular} & $20 \%$ PFTBA & Pluronic F-68 & $\mid \begin{array}{c}\text { Krebs-Ringer } \\
\text { bicarbonate } \\
\text { solution }\end{array}$ & $0.45 \times 10^{-2}$ & $\begin{array}{l}\text { Ruland } \\
\text { et al., } 1987\end{array}$ \\
\hline & $\begin{array}{c}\text { Perftoran } \\
\text { (Perftoran } \\
\text { Company, RU) }\end{array}$ & $\begin{array}{c}12 \% \text { PFD } \\
3 \% \text { PFMCP }\end{array}$ & $\begin{array}{c}6.5 \% \text { Proxanol } \\
268\end{array}$ & $\begin{array}{c}\mathrm{NaCl}, \mathrm{KCl}, \\
\mathrm{MgCl}_{2}, \\
\mathrm{NaHCO}_{3}, \\
\mathrm{NaH}_{2} \mathrm{PO}_{4}, \\
\text { glucose, } \mathrm{H}_{2} \mathrm{O}\end{array}$ & $0.06 \times 10^{-2}$ & $\begin{array}{l}\text { Maevsky } \\
\text { et al., } 2005\end{array}$ \\
\hline \multirow{3}{*}{$2^{\text {nd }}$} & \begin{tabular}{|c|} 
Oxycyte \\
(Oxygen \\
Biotherapeutics, \\
Inc., US; \\
previously \\
Synthetic Blood \\
International Inc., \\
US) \\
\end{tabular} & $\begin{array}{c}60 \% \\
\text { TBPFCH }\end{array}$ & EYP & $\mathrm{n} / \mathrm{a}$ & $1.27 \times 10^{-2}$ & $\begin{array}{l}\text { Yacoub } \\
\text { et al., } 2014\end{array}$ \\
\hline & $\begin{array}{c}\text { Oxyfluor } \\
\text { (HemaGen/PFC, } \\
\text { US) }\end{array}$ & $78 \%$ PFDCO & $\begin{array}{c}\text { EYP, } \\
\text { safflower oil }\end{array}$ & $\mathrm{n} / \mathrm{a}$ & $0.13 \times 10^{-2}$ & $\begin{array}{l}\text { Rémy } \\
\text { et al., } 1999\end{array}$ \\
\hline & $\begin{array}{c}\text { Oxygent } \\
\text { (Alliance } \\
\text { Pharmaceutical } \\
\text { Corp., US) }\end{array}$ & $\begin{array}{c}58 \% \\
\text { perflubron } \\
2 \% \text { PFDB }\end{array}$ & $3.6 \%$ EYP & $\begin{array}{c}\mathrm{NaCl}, \\
\text { EDTA, } \\
\alpha \text {-tocopherol, } \\
\text { phosphate } \\
\text { buffer }\end{array}$ & $2.32 \times 10^{-2}$ & $\begin{array}{l}\text { Hill } \\
\text { et al., } 2002\end{array}$ \\
\hline \multirow[t]{2}{*}{$\begin{array}{c}\text { currently in } \\
\text { progress }\end{array}$} & $\begin{array}{l}\text { "Columbian } \\
\text { emulsion" }\end{array}$ & $\begin{array}{c}58 \% \\
\text { perflubron }^{\circledR}\end{array}$ & $\begin{array}{c}3 \% \text { soybean } \\
\text { lecithin }\end{array}$ & \begin{tabular}{|c|}
$\mathrm{NaCl}$, \\
glucose, \\
glycerol, \\
$\alpha$-tocopherol, \\
phosphate \\
buffer \\
\end{tabular} & $\mathrm{n} / \mathrm{a}$ & $\begin{array}{l}\text { Gardeazabal } \\
\text { et al., } 2008\end{array}$ \\
\hline & "French emulsion" & $\begin{array}{c}90 \% \\
\text { perflubron }\end{array}$ & \begin{tabular}{|c|}
$4 \%$ EYP \\
$2.5 \%$ diblock \\
perfluoro- \\
/hydrocarbon \\
compound
\end{tabular} & $\begin{array}{l}\text { phosphate } \\
\text { buffer }\end{array}$ & $\mathrm{n} / \mathrm{a}$ & $\begin{array}{l}\text { Audonnet- } \\
\text { Blaise et al., } \\
2006\end{array}$ \\
\hline
\end{tabular}

$O_{2}$ c.c. - oxygen carrying capacity $\left(\mathrm{cm}^{3} \mathrm{O}_{2} \mathrm{dm}^{-3} \mathrm{kPa}^{-1}\right) ; \mathrm{n} / \mathrm{a}$ - not available

liquid PFCs: PFDB - 1-bromo-perfluorodecane; perflubron ${ }^{\circledR}$ - 1-bromo-perfluorooctane; PFD - perfluorodecalin; PFDCO - perfluorodichlorooctane, PFMCP - perfluoromethylocyclohexylpiperidin,

PFTBA - perfluorotributylamine, PFTPA - perfluorotripropylamine, TBPFCH - tributyloperfluorocyclohexane; surfactants/emulsifiers: EYP - egg yolk phospholipid; 


\section{LIQUID PFC-BASED GAS CARRIERS IN VARIOUS CELL CULTURE SYSTEMS}

Oxygen has a low solubility in water and in aqueous media. Additionally, the concentration of oxygen dissolved in culture media decreases during heating the broth, and the presence of dissociated microelements in the culture medium also influence negatively oxygen solubility. Combinations of spargers and various types of agitators, as well as air-lift systems are typical and commonly used mixing-and-aerating systems applied in a range of bioprocesses related to living cells. However, their application can result in undesired by-product production (e.g. biosynthesis and secretion of stressderived metabolites as the response to environmental stressors, leak of metabolites through weakened cell membrane) (Enfors et al., 2001; Garcia-Ochoa and Gomez, 2009; Neubauer and Junne, 2010) or even in structural disruption of cells as a result of the hydrodynamic cell stress caused by high shear forces generated during mechanical mixing and/or continuous bubble aeration of culture broth/medium due to turbulence intermittency (Bałdyga and Pohorecki, 1998; Garcia-Ochoa et al., 2013; Pohorecki et al., 2001). All these effects negatively affect biomass performance, and contribute to bioprocess yield decrease.

Water-immiscible carriers of respiratory gases are the alternative to conventional aeration systems applied in a range of bioreactors and miniaturised-scale culture systems. Such agents exhibit one common property - they have greater capacity to solubilise the oxygen than water, i.e. the basic solvent of all culture media. Besides liquid PFCs, a few other organic materials have been applied in bioprocesses as gas (oxygen, mainly) carriers so far: saturated hydrocarbons, oils and modifiedhaemoglobin-based derivatives. Initially, water-immiscible gas carriers have been utilised in the field of biomedical engineering, e.g. haemoprotein-based derivatives and emulsified liquid PFCs as intravascularly applied temporary blood substitutes (Bucci, 2009; Kim, 2007; Kołtuniewicz, 2014) or pure liquid PFCs as media suitable for liquid ventilation procedures (Kaisers et al., 2003; Tawfic and Kausalya, 2011). Nevertheless, droplets or layer of gas saturated water-immiscible liquid carriers (liquid PFCs, mainly) can be applied to enhance gas supply (e.g. in the case of oxygen, ethene) or removal (e.g. in the case of carbon dioxide) through liquid-liquid (i.e. PFC-medium) interfacial area in culture systems. Examples of bioprocess engineering applications of liquid PFC-based gas carriers in culture systems of various types of cells are reviewed in Table 4.

Water-immiscible liquid PFC-based gas carriers were applied in submerged cultures of all main types of cells utilised in bioprocess engineering, i.e. microorganisms (bacteria, yeasts, microalgae), plant and animal (insects, mammalian, human) cells. To date, depending on the specificity of a particular culture, liquid PFCs were used to intensify the transfer of the following gases: oxygen, carbon dioxide, nitrogen, nitrous oxide and ethene. The main benefits of bioprocesses carried out in the presence of a gas-saturated liquid PFC compared to traditional cultures (without liquid gas carrier) include: (i) providing additional liquid-liquid (i.e. liquid PFC - culture medium) interfacial area for effective mass transfer independent from gas-liquid interface typically occurring in culture vessel filled by aqueous broth/medium and air phase; (ii) enhanced gas absorption rate without the need for supplementary energy input for mixing the culture; (iii) reduction of the detrimental effects of mechanical damage of cells occurring during a conventional intensive mixing and bubble aeration; (iv) easy separation of liquid PFC from culture medium as well as its regeneration (e.g. in typical absorption column) and reuse (v) possibility to use liquid PFCs in an autoclave directly in culture vessel together with broth/medium prepared for culture (independent sterilisation of liquid PFCs via filtration is also possible). 


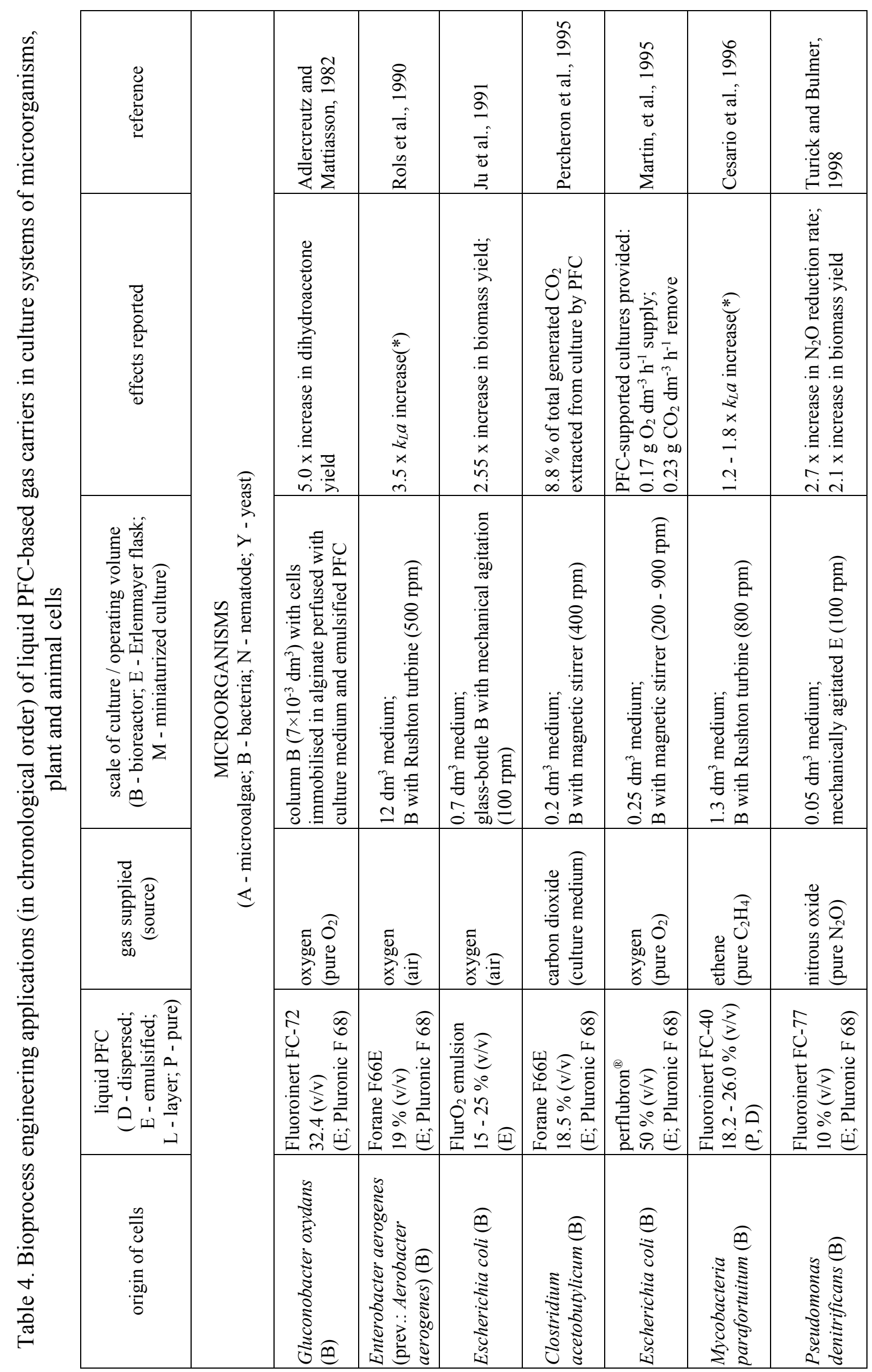




\begin{tabular}{|c|c|c|c|c|c|c|c|}
\hline $\begin{array}{l}2 \\
\text { बे } \\
\hat{0} \\
\frac{0}{11}\end{array}$ & 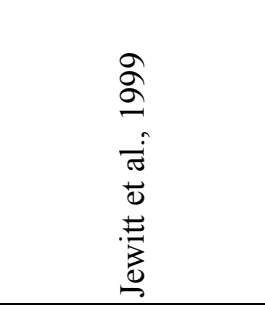 & 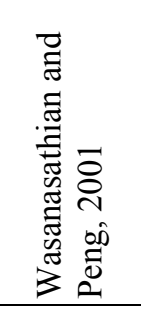 & $\begin{array}{l}\overrightarrow{8} \\
\text { i } \\
\overrightarrow{0} \\
: \overrightarrow{0}\end{array}$ & 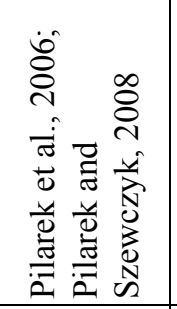 & 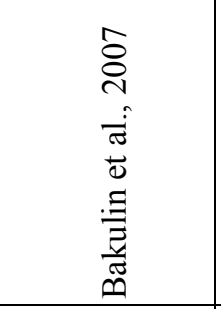 & 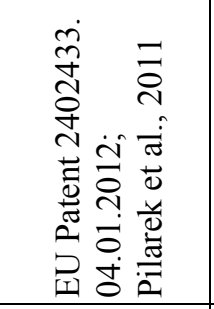 & 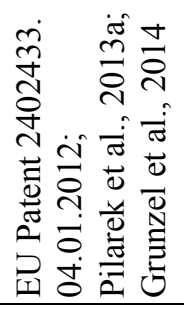 \\
\hline 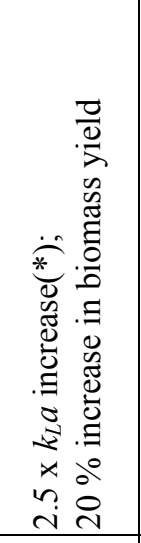 & 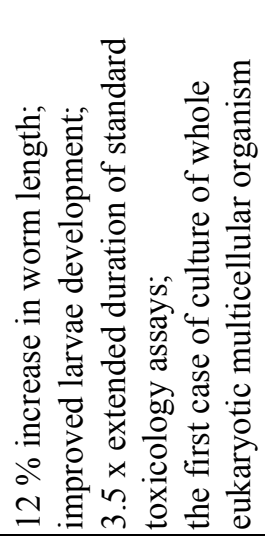 & 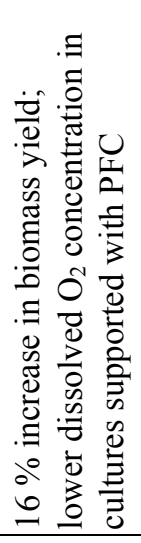 & 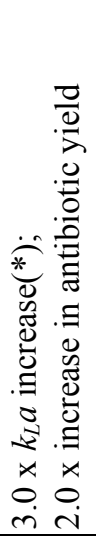 & 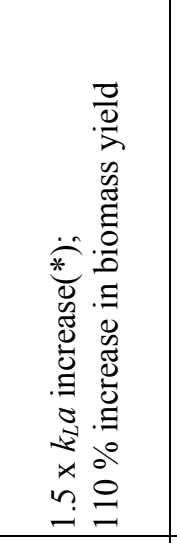 & 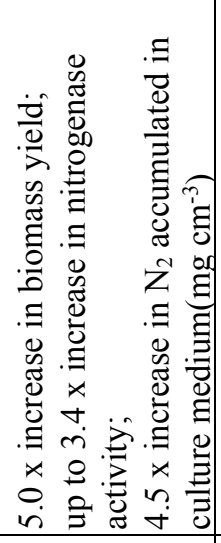 & 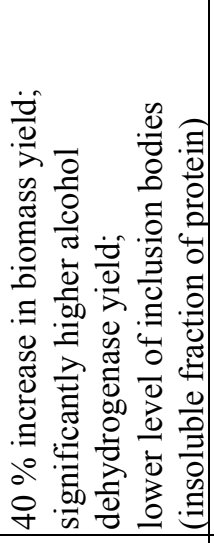 & 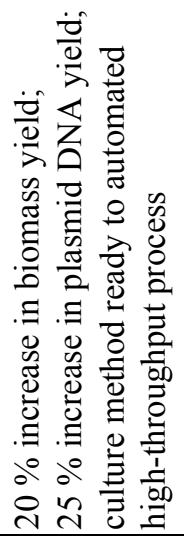 \\
\hline 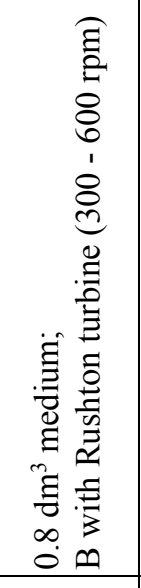 & 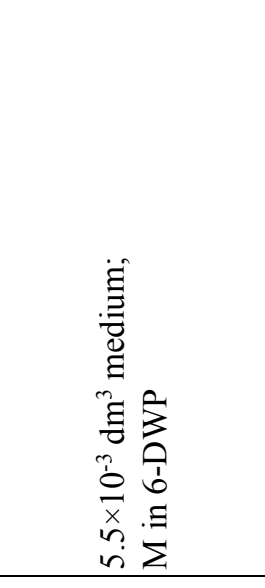 & 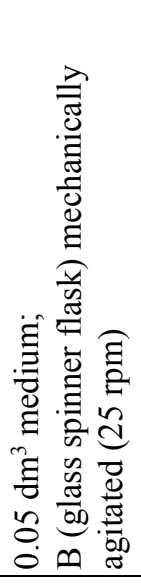 & 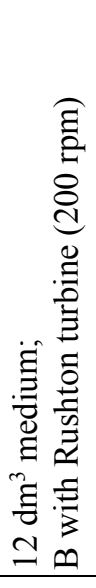 & 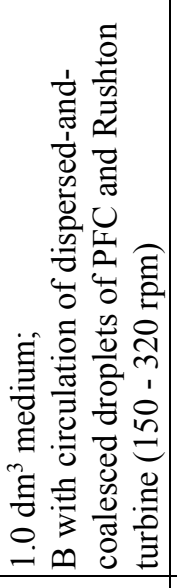 & 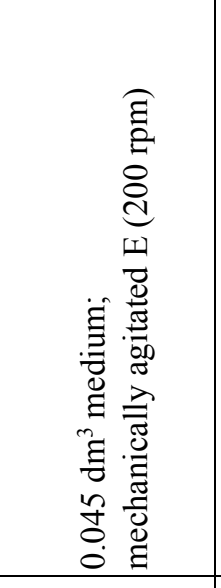 & 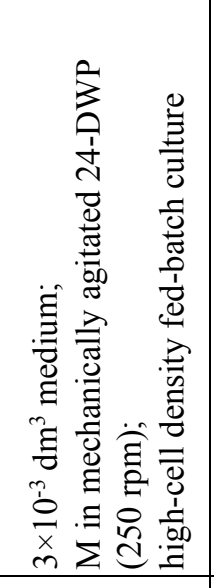 & 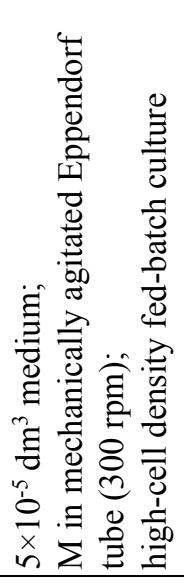 \\
\hline 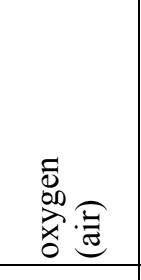 & 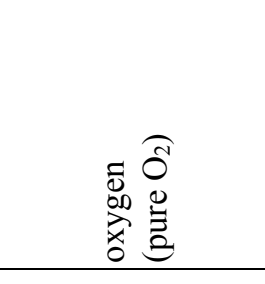 & 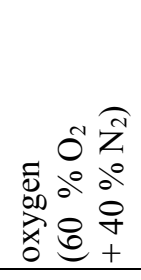 & 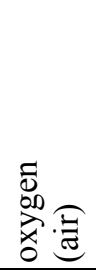 & 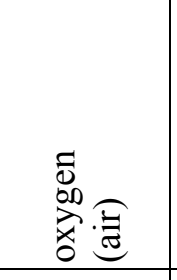 & 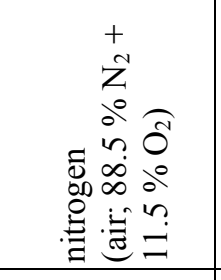 & 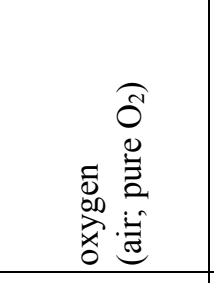 & 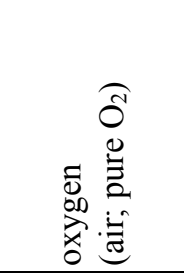 \\
\hline 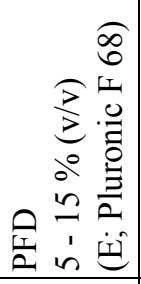 & 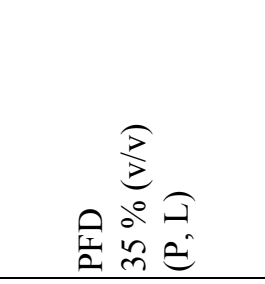 & 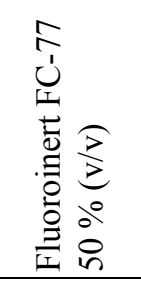 & 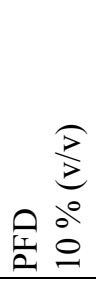 & 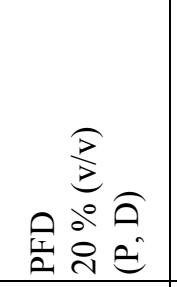 & 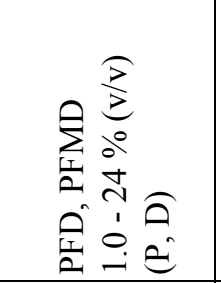 & 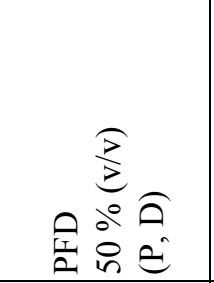 & 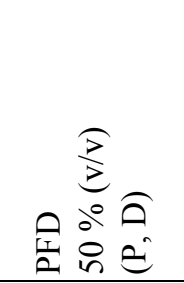 \\
\hline 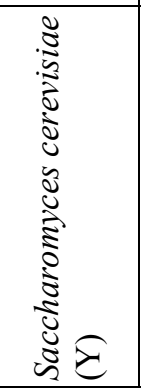 & 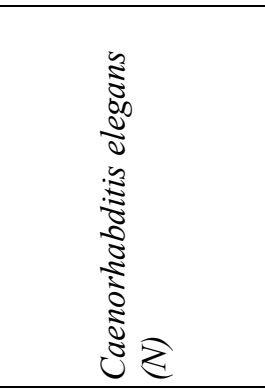 & 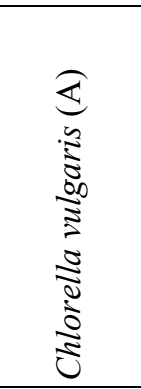 & 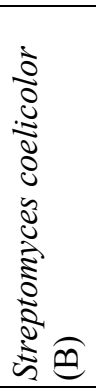 & 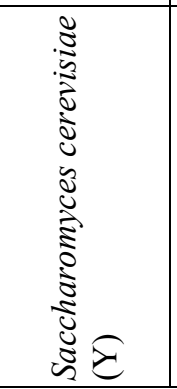 & 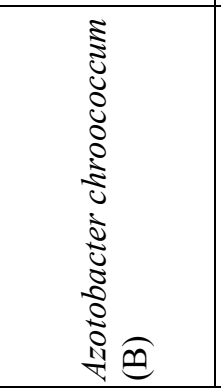 & 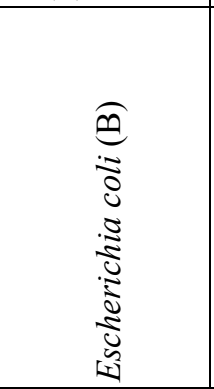 & 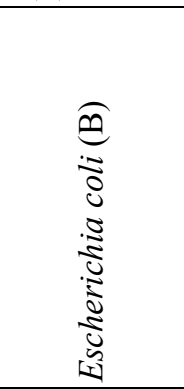 \\
\hline
\end{tabular}




\begin{tabular}{|c|c|c|c|c|c|c|c|}
\hline 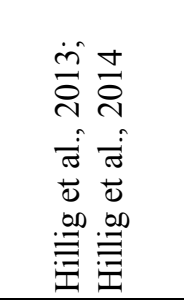 & 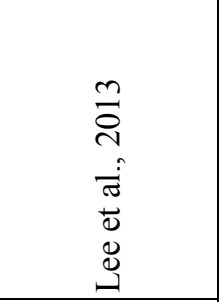 & & 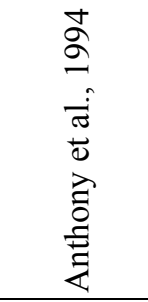 & $\begin{array}{l}0 \\
2 \\
0 \\
\vdots \\
\pi \\
0 \\
0 \\
0 \\
0 \\
0 \\
0 \\
3\end{array}$ & 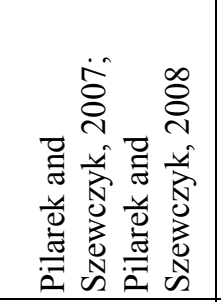 & 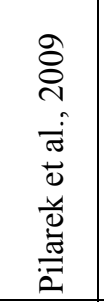 & 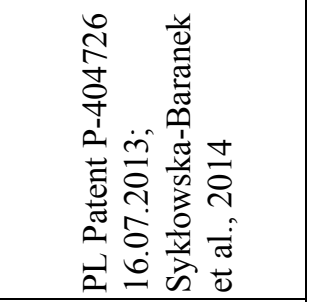 \\
\hline 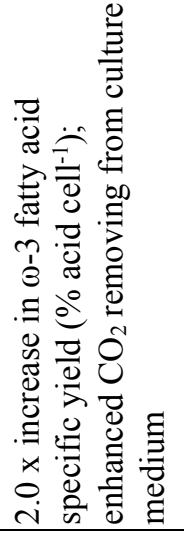 & 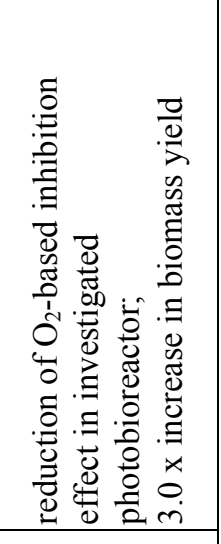 & & 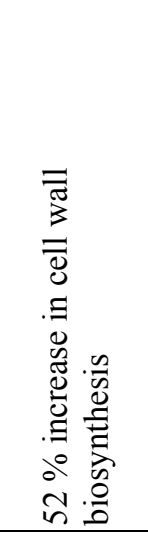 & 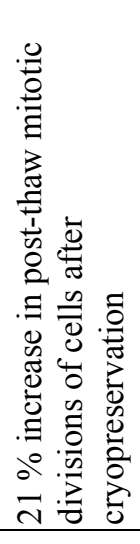 & 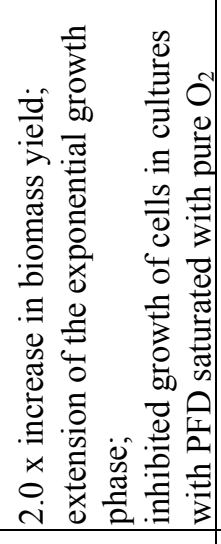 & 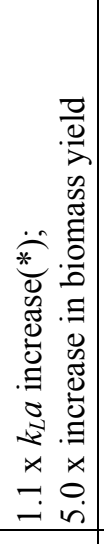 & 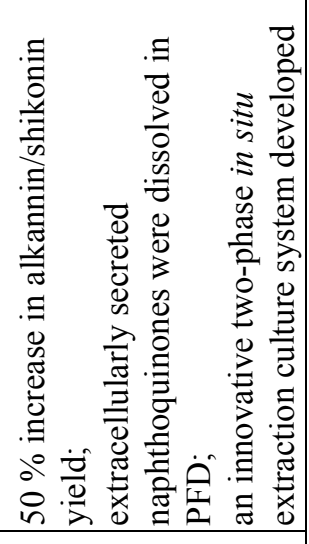 \\
\hline 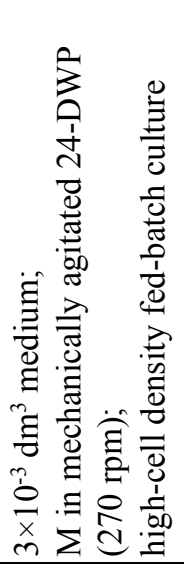 & 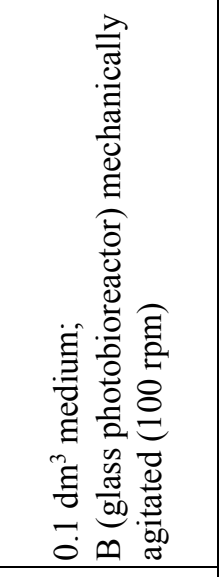 & 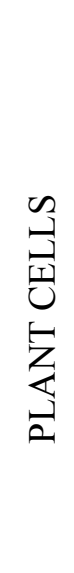 & 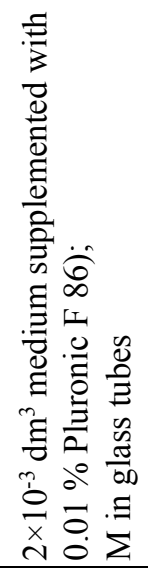 & 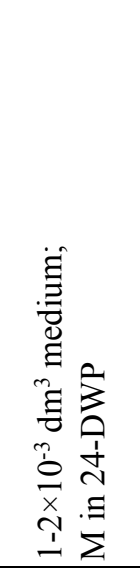 & 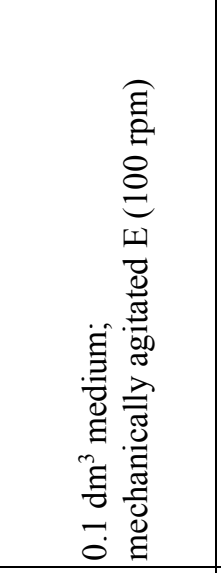 & 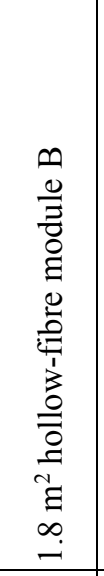 & 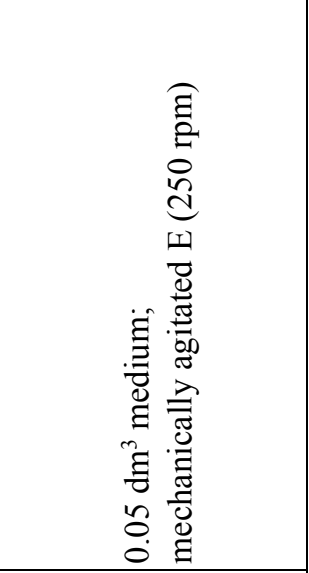 \\
\hline 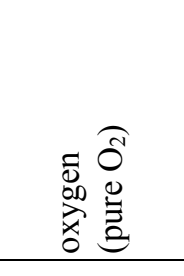 & 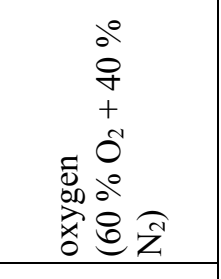 & & 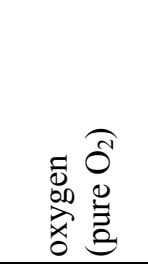 & 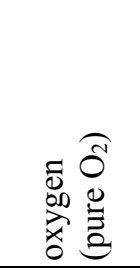 & 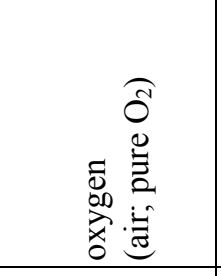 & 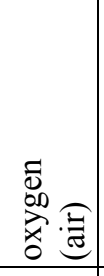 & 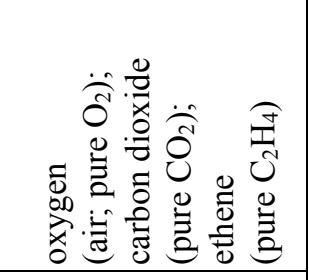 \\
\hline 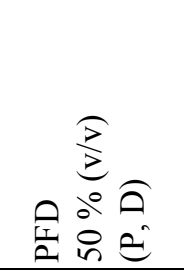 & 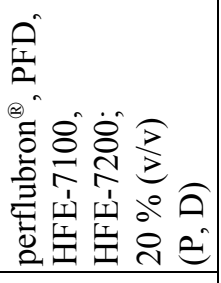 & & 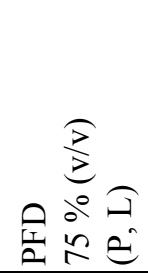 & 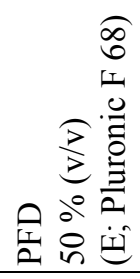 & 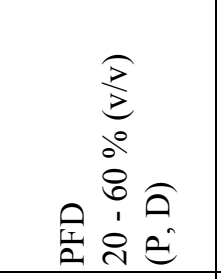 & 空 & 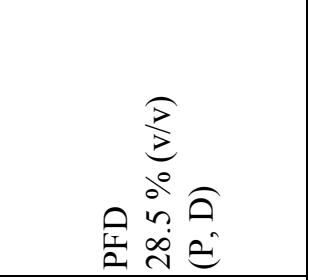 \\
\hline 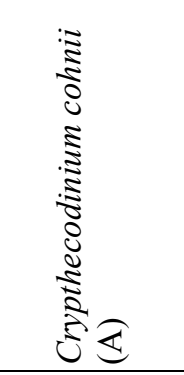 & 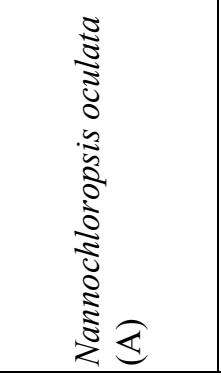 & & 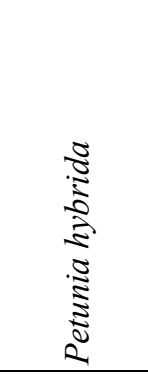 & 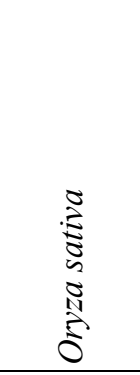 & 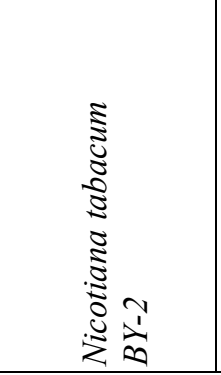 & 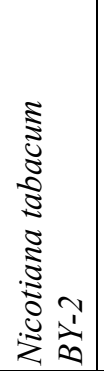 & 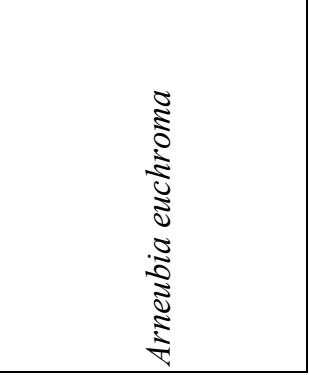 \\
\hline
\end{tabular}


Liquid perfluorochemicals as flexible and efficient gas carriers applied in bioprocess engineering...

\begin{tabular}{|c|c|c|c|c|c|c|c|c|}
\hline & 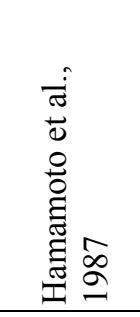 & 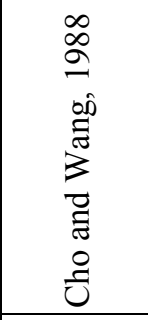 & 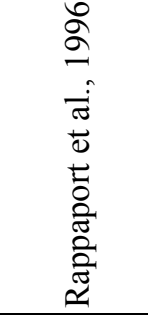 & $\begin{array}{l}\infty \\
2 \\
\vdots \\
\vdots \\
\tilde{\sigma} \\
\tilde{\omega} \\
\dot{\tilde{\omega}}\end{array}$ & 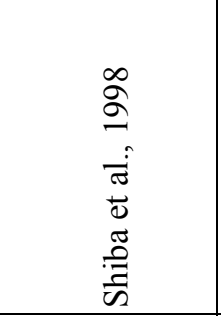 & 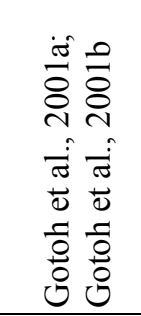 & 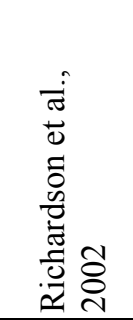 & 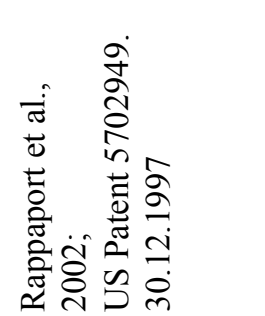 \\
\hline & 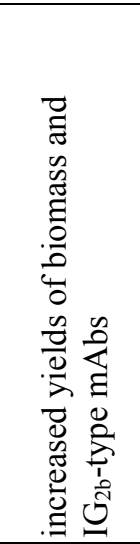 & 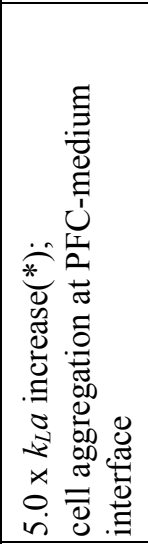 & 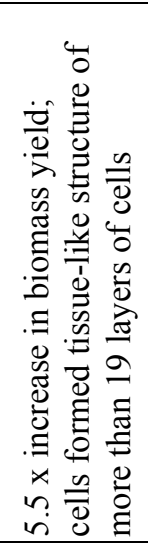 & 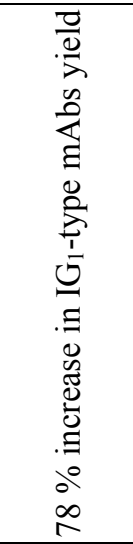 & 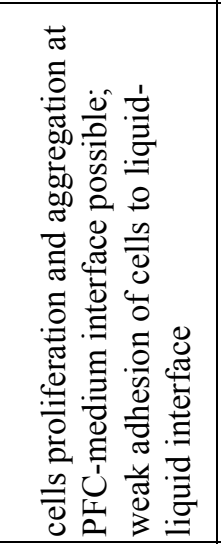 & 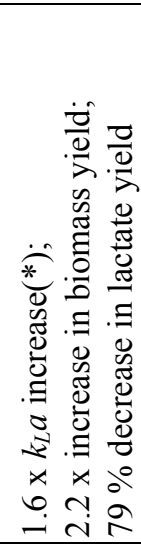 & 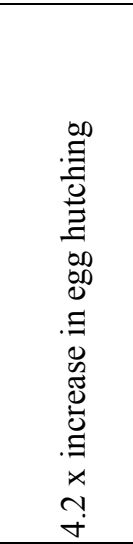 & 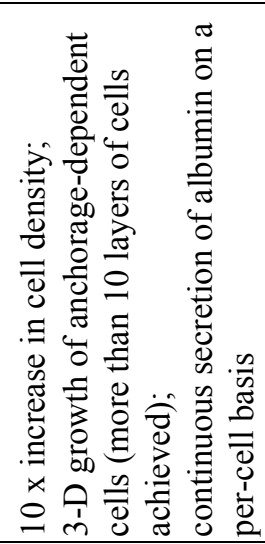 \\
\hline 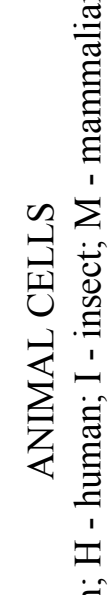 & 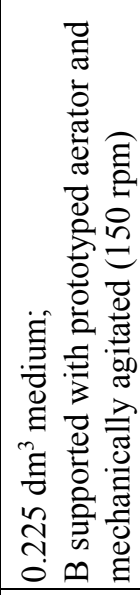 & 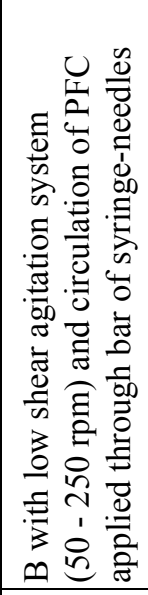 & 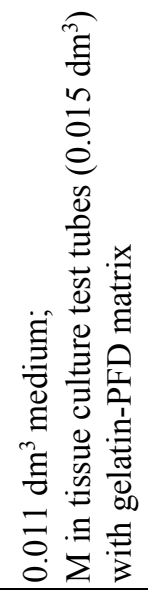 & 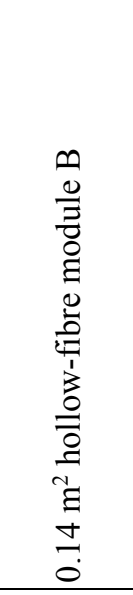 & 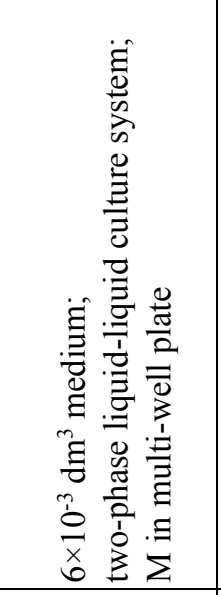 & 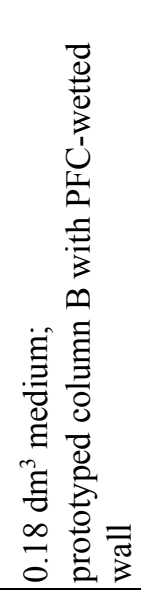 & 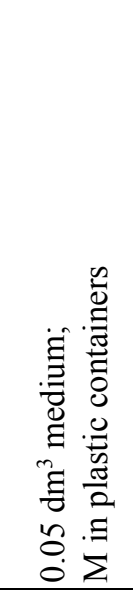 & 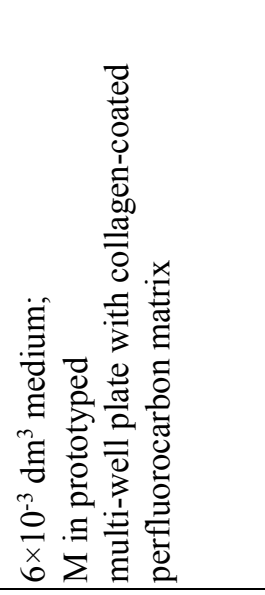 \\
\hline 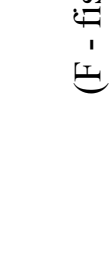 & 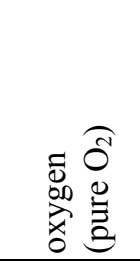 & 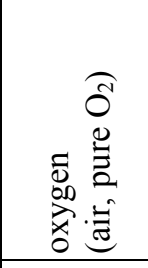 & 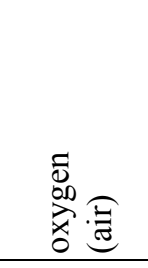 & 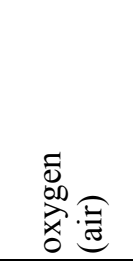 & 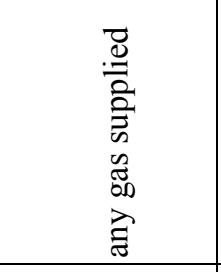 & 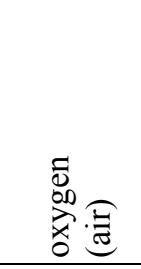 & 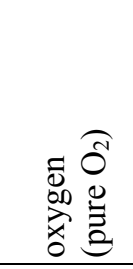 & 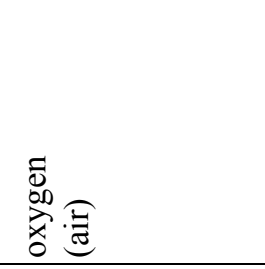 \\
\hline & 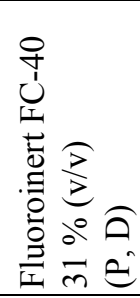 & 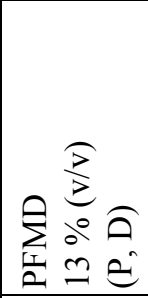 & 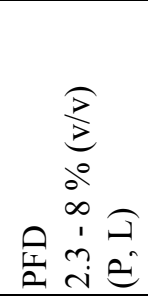 & 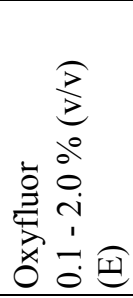 & 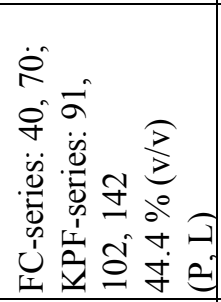 & 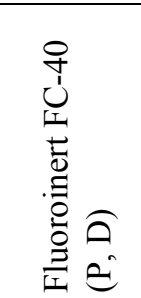 & 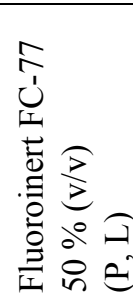 & 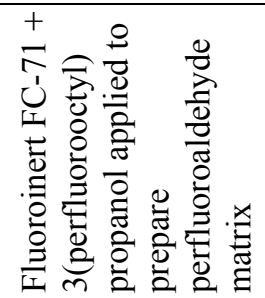 \\
\hline & 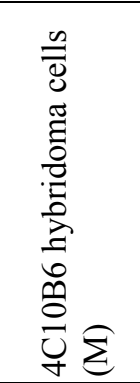 & 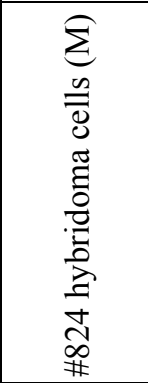 & 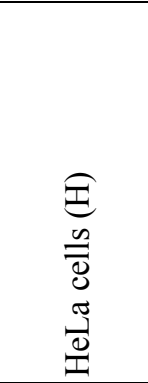 & 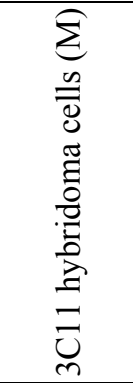 & 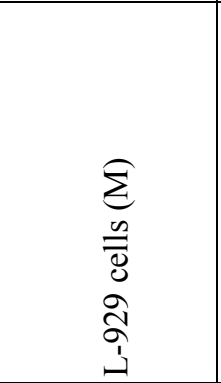 & $\begin{array}{l}\frac{n}{0} \\
\overline{0} \\
\frac{8}{\infty}\end{array}$ & 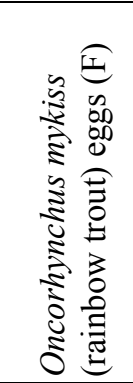 & $\begin{array}{l} \pm \\
0 \\
0 \\
0 \\
0 \\
0 \\
0 \\
0 \\
0\end{array}$ \\
\hline
\end{tabular}




\begin{tabular}{|c|c|c|c|c|}
\hline 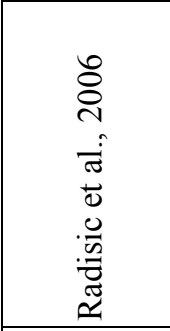 & 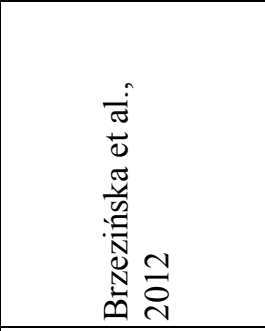 & 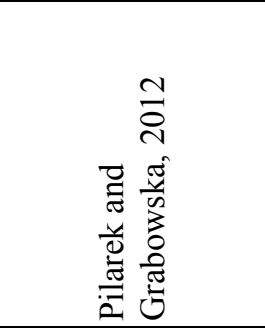 & 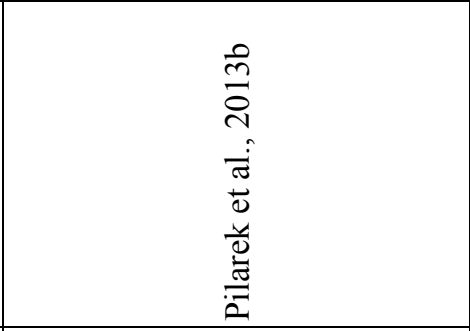 & 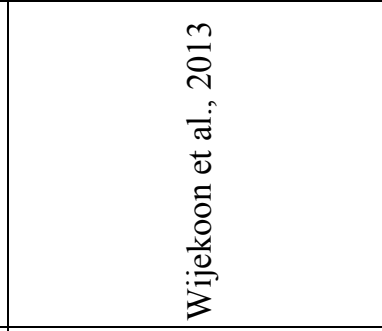 \\
\hline 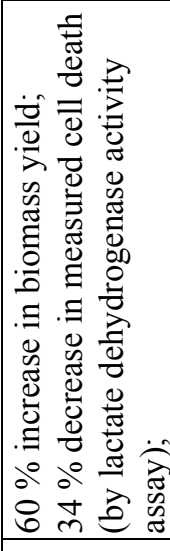 & 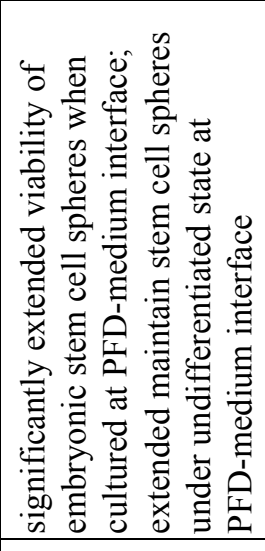 & 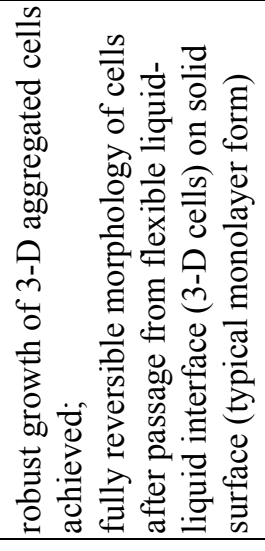 & 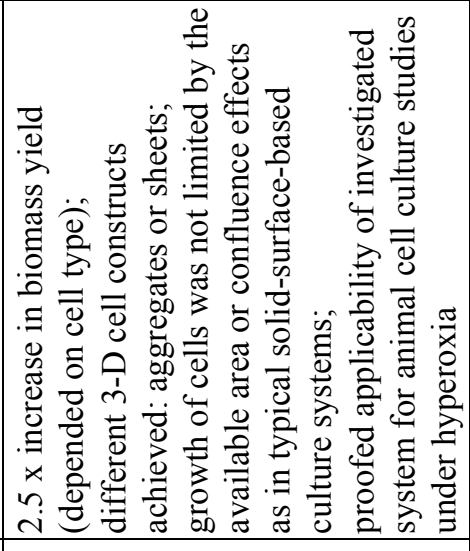 & 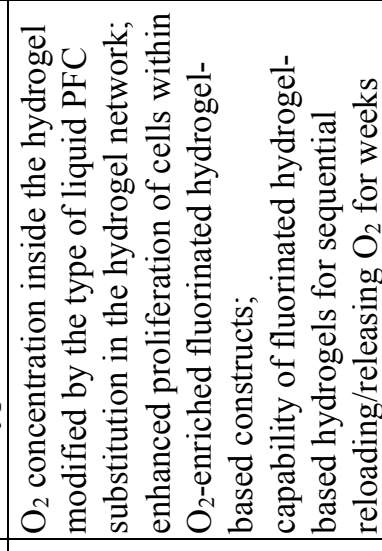 \\
\hline 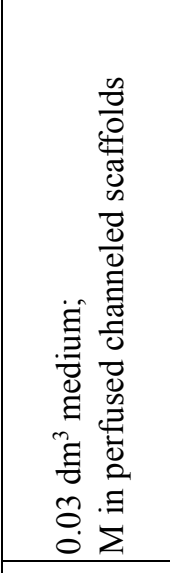 & 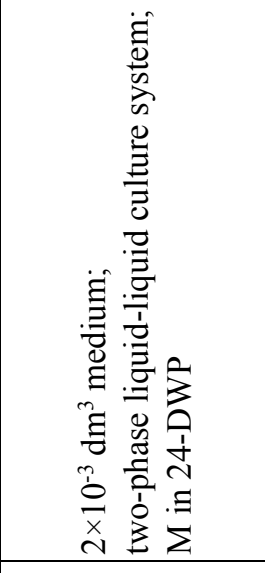 & 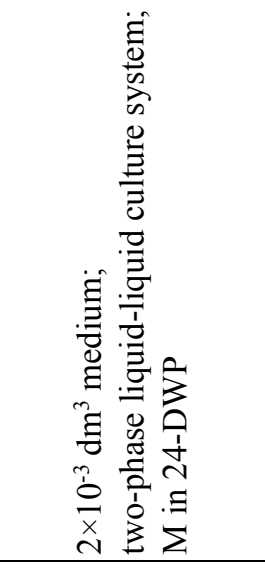 & 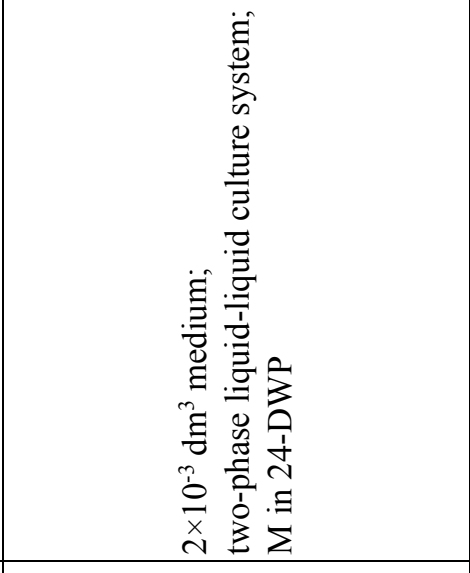 & 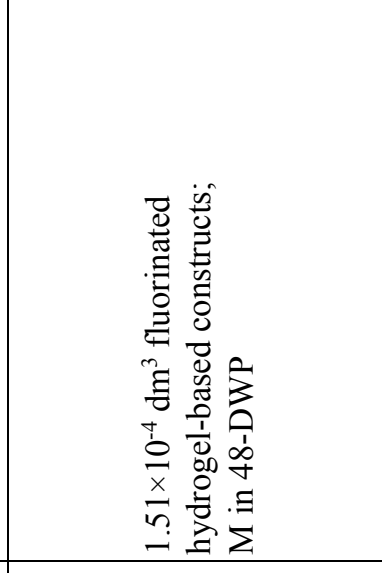 \\
\hline 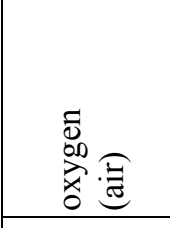 & 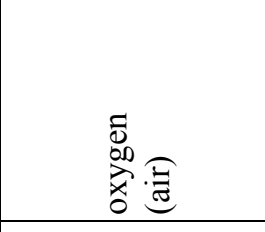 & 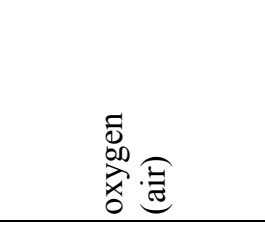 & 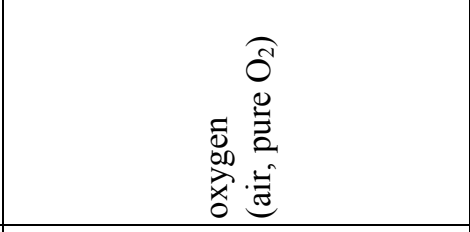 & 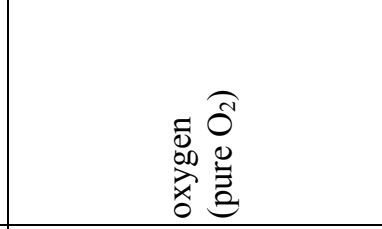 \\
\hline 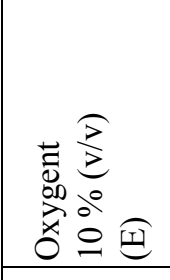 & 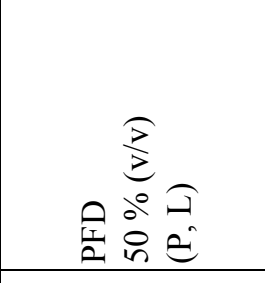 & 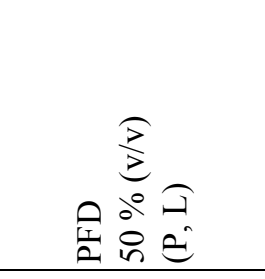 & 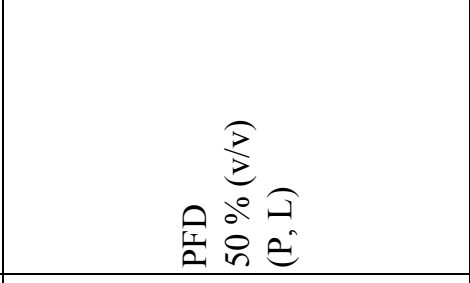 & 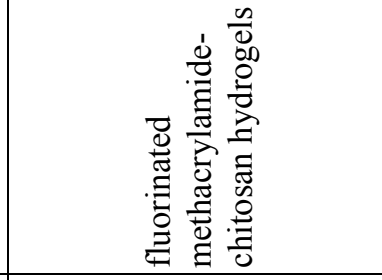 \\
\hline 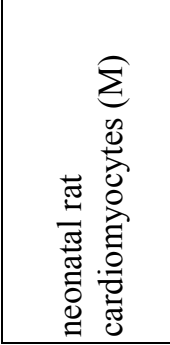 & 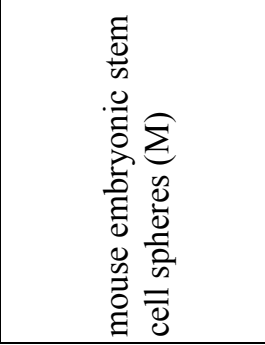 & 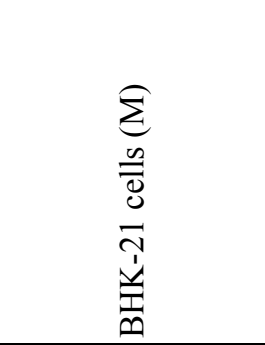 & 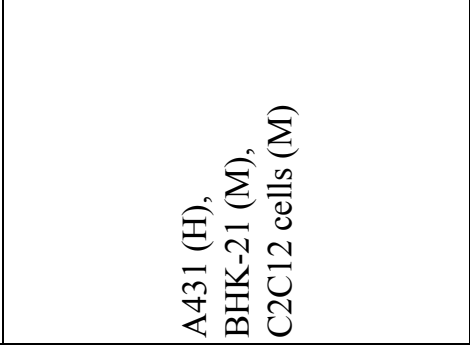 & 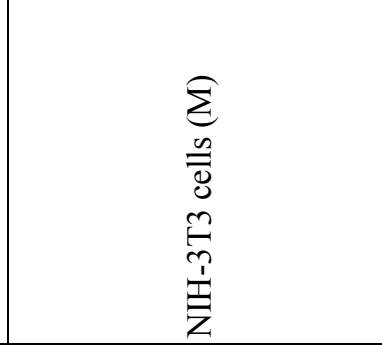 \\
\hline
\end{tabular}


Liquid perfluorochemicals as flexible and efficient gas carriers applied in bioprocess engineering...

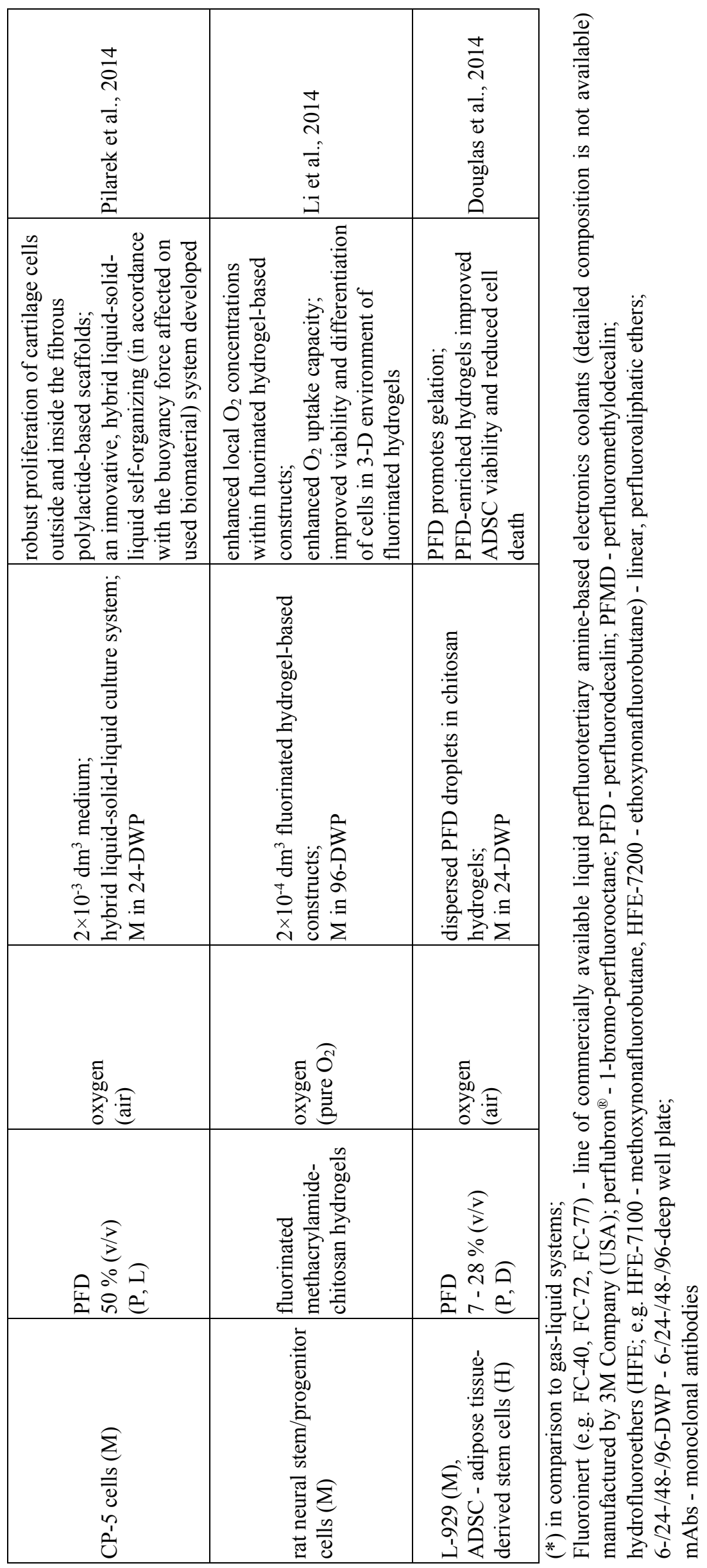




\subsection{PFC-mediated oxygen transfer intensification}

Regardless of the type of cultured cells, the effects of supplying oxygen into culture media via perfluorinated carriers have been studied frequently. Generally, the application of liquid PFC-based oxygen carriers in culture systems had positive effects on the rate of oxygen absorption and thus enhanced biomass and bioproduct yields. In the case of submerged cultures of microbial cells, the highest increase of volumetric liquid-side mass transfer coefficient $\left(k_{L} a\right)$ of up to 3.5 times, which been achieved when emulsified Forane F66E has been applied for oxygenation of Enterobacter aerogenes (synonym: Aerobacter aerogenes) culture performed in $12 \mathrm{dm}^{3}$ stirred tank (500 rpm) in comparison to a process with typical bubble aeration (Rols et al., 1994). Liquid PFC-supported bioprocesses resulting in the increase of $k_{L} a$ from 1.2 to 3.0 times have been reported (see Table 4). In the case of enhancing biomass production, the highest increase in biomass yield (up to 2.22 times) has been reported by Ju et al. (1991) for Escherichia coli culture with oxygenation enhanced by $\mathrm{FlurO}_{2}$.

Elibol (2001) informed of up to 2.0 fold increase in Streptomyces coelicolor secondary metabolite production in culture performed in $12 \mathrm{dm}^{3}$ bioreactor with Rushton turbine $(200 \mathrm{rpm})$ and supported with dispersed aerated PFD. More recently it has been proved that water-immiscible liquid PFC-based oxygen carriers are also feasible agents in miniaturised culture systems. A significantly higher yield of genetically modified alcohol dehydrogenase as well as a lower level of inclusion bodies (i.e. insoluble fraction of not-correctly folded protein molecules) achieved in milliliter-scale of dispersed PFD containing cultures of $E$. coli has been reported by Pilarek et al. (2011). The same group has also informed of a $25 \%$ increase in plasmid DNA yield biosynthesised in E. coli cells cultured in PFDsupported microliter-scale system (Grunzel et al., 2014; Pilarek et al., 2013). Such a huge range of culture volumes (from $10^{-5}$ to $10^{1} \mathrm{dm}^{3}$ ) which has been reviewed in Table 4 (as well as discussed above) clearly indicates that perfluorinated oxygen carriers are very flexible bioengineering tools for gas transfer intensification in scaling-up or scaling-down of bioprocesses.

Also in the case of in vitro cultures of cells isolated from multicellular organisms, liquid PFCs have been applied mainly as carriers of oxygen. The application of the PFD-mediated oxygenation system in Nicotiana tabacum BY-2 (Bright Yellow 2) cultures performed in a hollow-fibre bioreactor has resulted in 1.1 time $k_{L} a$ increase, as well as up to 5 times higher biomass yield in comparison to the culture system utilising atmospheric air as oxygenation medium (Pilarek et al., 2009). A hollow-fibre bioreactor has been also utilised for monoclonal antibody $(\mathrm{mAb})$ production in cultures of mouse $3 \mathrm{C} 11$ hybridoma cells (Shi et al., 1998). The application of aerated Oxyfluor emulsion as an oxygenation agent has resulted in a $78 \%$ increase in yield of $\mathrm{IG}_{1}$-type $\mathrm{mAbs}$.

More recent studies on the application of liquid PFCs in animal cell cultures were focused on cultures of 3-D aggregated anchorage-dependent (adherent) mammalian and human cells on a of liquid PFC in hybrid liquid-liquid (PFC-medium) systems. In vitro development of 3-D aggregates of cells which typically grow in monolayers (due to growth-inhibition confluence effect) when they are cultured directly on a layer of pure (i.e. non-emulsified and non-dispersed) liquid PFC, has been originally reported by Shiba et al. (1998) and further elaborated by Brzezińska et al. (2012), Pilarek and Grabowska (2012) as well as Pilarek et al. (2013b). Finally, liquid-liquid system has been studied as a new way of a cartilage implant development (Pilarek et al., 2014) and it has been proven that the system is suitable for inoculation and further enhanced growth of CP-5 chondrocytes on biodegradable, fibrous poly-lactide (PLA) scaffolds placed on the interfacial area between immiscible layers of PFD and the medium. From the bioprocess engineering point of view, such a hybrid system simultaneously enables the adhesion of adherent cells to fibers of PLA-based scaffolds, as well as, due to a PFC phase, enhances the mass transfer in the case of supplying/removing of respiratory gases, i.e., $\mathrm{O}_{2}$ and $\mathrm{CO}_{2}$. Another way for liquid PFC-mediated mass transfer intensification in biodegradable scaffolds has been proposed by Douglas et al. (2014). Oxygenated PFD has been successfully applied in the form of dispersed droplets to thermosensitive injectable scaffolds based on chitosan hydrogels in order to 
improve human adipose-tissue derived stem cells growth. The incorporation of oxygenated PFD improved the suitability of studied hydrogels as bone regeneration materials.

\subsection{PFC-mediated transport of other gases}

In the field of water-immiscible liquid gas carriers applied in culture systems, removal of carbon dioxide from broth/medium via liquid PFCs has been much less investigated (e.g. by Percheron et al. (1995) in the case of bacteria culture and by Sykłowska-Baranek et al. (2014) in the case of plant cells) than the problem of oxygen supply. Nevertheless, accumulation of $\mathrm{CO}_{2}$ which is gas continuously generated by cells and major waste product in culture media may cause detrimental effects in the cells, causing intracellular enzyme inhibition leading to death and further lysis of the cells. Because carbon dioxide is also well soluble in liquid PFCs, one can take advantage of the reversibility of the mechanisms of oxygen-supply and $\mathrm{CO}_{2}$-extraction from the culture medium/broth in bioprocesses supported with liquid PFCs. The phenomenon is currently successfully adopted in biomedical applications of liquid PFCs, such as liquid ventilation and temporary blood substitutes. In the case of supply of non-respiratory gases (i.e. gases other than $\mathrm{O}_{2}$ and $\mathrm{CO}_{2}$ ), liquid PFCs have been applied as water-immiscible carriers of nitrogen, nitrous oxide or ethene (see Table 4). The way of enhancing ethene transfer is important particularly in the development of plant cell cultures because such gaseous compound is one of the biologically active signal molecules which regulate metabolism and growth of plant cells. Ethene has very poor solubility in water and liquid PFC-mediated supply of this compound has great potential of applicability in plant cell cultures. Up to date the effects of ethene-saturated PFD application have been studied only in the case of submerged cultures of Arneubia euchroma cells (Sykłowska-Baranek et al., 2014) in which $26 \mathrm{x}$ higher value of the ratio between alkanin/shikonin, i.e. extracellularly secreted naphtoqinone-based plant secondary metabolites, has been achieved in comparison to cultures without PFD.

\section{SUMMARY AND OUTLOOK}

During the past thirty years many studies have shown that various liquid PFCs can be successfully applied as carriers of different kinds of gases (mainly $\mathrm{O}_{2}$, but also $\mathrm{CO}_{2}, \mathrm{~N}_{2} \mathrm{O}$ and ethene) to supply them into culture media or as scavengers of gaseous cellular by-products. Data published up to date clearly revealed that the application of a perfluorinated gas carrier can facilitate mass transport in different types and scales of microbial, plant cell and animal cell culture systems. One of the main reasons for this is an increased value of the driving force of the process due to the relatively higher values of gas solubility (e.g. in the case of dissolved oxygen) in perfluorinated compound added to culture system than in aqueous medium. The second reason is the presence of a higher interfacial area in the case of liquid PFCs applied in dispersed forms, which leads to higher $k_{L} a$ values. On balance, the above findings indicate that liquid PFCs can be recognised as very flexible bioengineering tools for gas transfer intensification in bioprocess engineering.

However, no liquid PFC-based mass transfer intensification method has been implemented in a real scaled-up industry-scale bioprocess installation so far. One of the main reasons why liquid PFCs are still rather rarely applied in the field of bioprocess engineering is the relatively high cost of perfluorinated compounds, which makes their use in large-scale bioprocesses uneconomical. Nevertheless, liquid PFCs could be successfully used in scaled-down miniature-scale cell culture systems to prevent oxygen limitation during grow to high cell densities. In miniaturised-scale culture formats, the costs of perfluorinated compounds are insignificant due to their small volumes. It may be argued that liquid PFC-mediated gas transfer would also offer benefits in the automation of bioprocesses and in microbioreactor cultures of various kinds of cells, especially in high throughput 
screening approaches in which the prevention of cells from decrease of dissolved oxygen concentration as well as increase of dissolved carbon dioxide concentration are still unsolved problems.

\section{SYMBOLS}

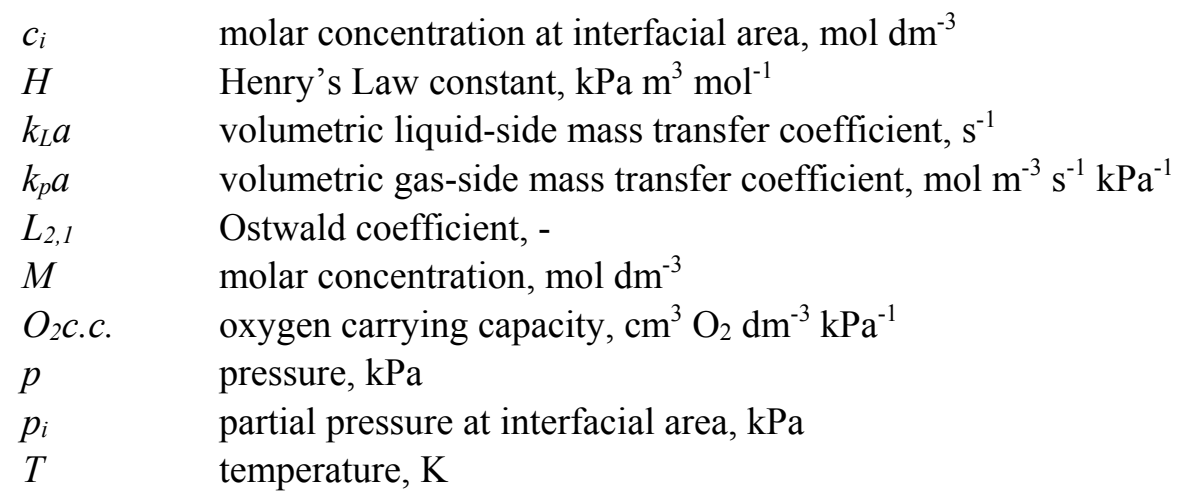

Abbreviations perfluorochemicals

perflubron ${ }^{\circledR}$ 1-bromo-perfluorooctane

PFC perfluorochemical (synonym: perfluorocarbon)

PFD perfluorodecalin

PFDB 1-bromo-perfluorodecane

PFDCO perfluorodichlorooctane

PFMCP perfluoromethylocyclohexylpiperidin

PFMD perfluoromethylodecalin

PFTBA perfluorotributylamine

PFTPA perfluorotripropylamine

PLA polylactide

PTFE poly(tetrafluoroethylene) (Teflon $\left.{ }^{\circledR}\right)$

TBPFCH tributyloperfluorocyclohexane

cell lines

\#824 mouse-derived hybridoma cells

3C11 mouse-derived hybridoma cells

4C10B6 mouse-derived hybridoma cells

A431 human epidermoid carcinoma cells

ADSC adipose tissue-derived stem cells

BHK-21 Syrian hamster kidney normal cells

$\mathrm{C} 2 \mathrm{C} 12$ mouse myoblasts

CP-5 bovine articular cartilage progenitor cells

HeLa human epithelial cervix adenocarcinoma cells

Hep G2 human hepatocellular carcinoma cells

L-929 mouse subcutaneous connective tissue fibroblasts

NIH-3T3 mouse embriogenic fibroblasts

Sf9 Spodoptera frugiperda ovarian cells

other

DWP

EYP

$\mathrm{Hb}$

deep well plate

HFE

egg yolk phospholipid

$\mathrm{mAb}$

haemoglobin

hydrofluoroether

monoclonal antibody 


\section{REFERENCES}

Adlercreutz P., Mattiasson B., 1982. Oxygen supply to immobilized cells. Eur. J. Appl. Microbiol. Biotechnol., 16, 165-170. DOI: 10.1007/BF00505826.

Anthony P., Davey M.R., Power J.B., Washington C., Lowe K.C., 1994. Synergistic enhancement of protoplast growth by oxygenated perfluorocarbon and Pluronic F-68. Plant Cell Rep., 13, 251-255. DOI: 10.1007/BF00233314.

Audonnet-Blaise S., Krafft M. P., Smani Y., Mertes P.M., Marie P.Y., Labrude P., Longrois D., Menu P., 2006. Resuscitation of severe but brief haemorrhagic shock with PFC in rabbits restores skeletal muscle oxygen delivery and does not alter skeletal muscle metabolism. Resuscitation, 70, 124-132. DOI: 10.1016/j.resuscitation.2005.11.014.

Bakulin M.K., Grudtsyna A.S., Pletneva A.Y., 2007. Biological fixation of nitrogen and growth of bacteria of the genus Azotobacter in liquid media in the presence of perfluorocarbons. Appl. Biochem. Microbiol., 43, 399-402. DOI: $10.1134 / \mathrm{S} 0003683807040072$.

Bałdyga J., Pohorecki R., 1998. Influence of turbulent mechanical stresses on microorganisms. Appl. Mech. Rev., 51, 121-140. DOI: 10.1115/1.3098987.

Bezinover D., Ramamoorthy S., Postula M., Weller G., Mahmoud S., Mani H., Kadry Z., Uemura T., Mets B., Spiess B., Brucklacher R., Freeman W., Janicki P.K., 2014. Effect of cold perfusion and perfluorocarbons on liver graft ischemia in a donation after cardiac death model. J. Surg. Res., 188, 517-526. DOI: 10.1016/j.jss.2014.01.045.

Bouchemal K., Briançon S., Perrier E., Fessi H., 2004. Nano-emulsion formulation using spontaneous emulsification: Solvent, oil and surfactant optimisation. Int. J. Pharm., 280, 241-251. DOI: 10.1016/j.ijpharm.2004.05.016.

Brzezińska M., Grabowska I., Dąbkowska K., Pilarek M., 2012. Układ typu ciecz/ciecz jako alternatywna metoda hodowli przestrzennej komórek adherentnych. Inż. Ap. Chem., 51, 101-102.

Bucci E., 2009. Thermodynamic approach to oxygen delivery in vivo by natural and artificial oxygen carriers. Biophysical Chem., 142, 1-6. DOI: 10.1016/j.bpc.20 08.12.0 09.

Cabrales P., Intaglietta M., 2013. Blood substitutes: evolution from noncarrying to oxygen- and gas-carrying fluids. ASAIO J., 59, 337-54. DOI: 10.1097/MAT.0b013e318291fbaa.

Castro C.I., Briceno J.C., 2010. Perfluorocarbon-based oxygen carriers: review of products and trials. Artif. Organs., 34, 622-34. DOI: 10.1111/j.1525-1594.2009.00944.x.

Centis V., Vermette P., 2009. Enhancing oxygen solubility using hemoglobin- and perfluorocarbon-based carriers. Front. Biosci., 14, 665-88. DOI: 10.2741/3272.

Cesário M.T., Turtoi M., Sewalt S.F.M., Beeftink H.H., Tramper J., 1996. Enhancement of the gas-to-water ethene transfer coefficient by a dispersed water-immiscible solvent: Effect of the cells. Appl. Microbiol. Biotechnol., 46: 497-502. DOI: 10.1007/s002530050850.

Chen Z., Yan F., Qiu L., Lu J., Zhou Y., Chen J., Tang Y., Texter J., 2010. Sustainable polymerizations in recoverable microemulsions. Langmuir, 26, 3803-3806. DOI: 10.1021/la100502x.

Cho M.H., Wang S.S., 1988. Enhancement of oxygen transfer in hybridoma cell culture by using a perfluorocarbon as an oxygen carrier. Biotechnol. Lett., 10, 855-860. DOI: 10.1007/BF01026995.

Costa Gomes M.F., Deschamps J., Menz D.H., 2004. Solubility of dioxygen in seven fluorinated liquids. J. Fluor. Chem., 125, 1325-1329. DOI: 10.1016/j.fluchem.2004.03.013.

Courrier H.M., Pons F., Lessinger J.M., Frossard N., Krafft M.P., Vandamme T.F., 2004. In vivo evaluation of a reverse water-in-fluorocarbon emulsion stabilized with a semifluorinated amphiphile as a drug delivery system through the pulmonary route. Int. J. Pharm., 282, 131-40. DOI: 10.1016/j.ijpharm.2004.06.011.

Davey M.R., Anthony P., Power J.B., Lowe K.C., 2003. Applications and benefits of a non-ionic surfactant and artificial oxygen carriers for enhancing post-thaw recovery of plant cells from cryopreservation. Adv. Exp. Med. Biol., 540, 139-146. DOI: 10.1007/978-1-4757-6125-2_20.

Davey M.R., Anthony P., Power J.B., Lowe K.C., 2005. Plant protoplast technology: current status. Acta Physiol. Plant., 27, 117-129. DOI: 10.1007/s11738-005-0044-0. 
Deschamps J., Menz D.H., Padua A.A.H., Costa Gomes M.F., 2007. Low pressure solubility and thermodynamics of solvation of oxygen, carbon dioxide, and carbon monoxide in fluorinated liquids. J. Chem. Thermodyn., 39, 847-854. DOI: 10.1016/j.jct.2006.11.012.

Dias A.M.A., Freire M., Coutinho J.A.P., Marrucho I.M., 2004. Solubility of oxygen in liquid perfluorocarbons. Fluid Phase Equilibr., 222-223, 325-330. DOI: 10.1016/j.fluid.2004.06.037.

Douglas T.E.L., Pilarek M., Kalaszczyńska I., Senderek I., Skwarczyńska A., Cuijpers V.M.J.I., Modrzejewska Z., Lewandowska-Szumieł M., Dubruel P., 2014. Enrichment of chitosan hydrogels with per fluorodecalin promotes gelation and stem cell vitality. Mater. Lett., 128, 79-84. DOI: 10.1016/j.matlet.2014.03.173.

Dumont E., Andrès Y., Le Cloirec P., 2006. Effect of organic solvents on oxygen mass transfer in multiphase systems: Application to bioreactors in environmental protection. Biochem. Eng. J., 30, 245-252. DOI: 10.1016/j.bej.2006.05.003.

Eaton D.F., Smart B.E., 1990. Are fluorocarbon chains "stiffer" than hydrocarbon chains? Dynamics of end-toend cyclization in a $\mathrm{C}_{8} \mathrm{~F}_{16}$ segment monitored by fluorescence. J. Am. Chem. Soc., 112, 2821-2823. DOI: 10.1021/ja00163a065.

Elibol M., 1999. Mass transfer characteristics of yeast fermentation broth in the presence of pluronic F-68. Process Biochem., 34, 557-561. DOI: 10.1016/S0032-9592(98)00126-5.

Elibol M., 2001. Improvement of antibiotic production by increased oxygen solubility through the addition of perfluorodecalin. J. Chem. Technol. Biotechnol., 76, 418-422. DOI: 10.1002/jctb.389.

Elliott S., 2011. Erythropoiesis-stimulating agents and other methods to enhance oxygen transport. $B r$. $J$. Pharmacol., 154, 529-541. DOI: 10.1038/bjp.2008.89.

Enfors S.O., Jahic M., Rozkov A., Xu B., Hecker M., Jürgen B., Krüger E., Schweder T., Hamer G., O'Beirne D., Noisommit-Rizzi N., Reuss M., Boone L., Hewitt C., McFarlane C., Nienow A., Kovacs T., Trägårdh C., Fuchs L., Revstedt J., Friberg P. C., Hjertager B., Blomsten G., Skogman H., Hjort S., Hoeks F., Lin H. Y., Neubauer P., van der Lans R., Luyben K., Vrabel P., Manelius Å., 2001. Physiological responses to mixing in large scale bioreactors. J. Biotechnol., 85, 175-185. DOI: 10.1016/S0168-1656(00)00365-5.

EU Patent 0164813. 18.12.1985. Method of cultivating animal or plant cells.

EU Patent 2402433. 04.01.2012. Method for increasing the expression of a recombinant protein and plasmid yield in an eukaryotic or prokaryotic high cell density culture.

Galaction A. I., Cascaval D., Oniscu C., Turnea M., 2004. Prediction of oxygen mass transfer coefficients in stirred bioreactors for bacteria, yeasts and fungus broths. Biochem. Eng. J., 20, 85-94. DOI: 10.1016/j.bej.2004.02.005.

Garcia-Ochoa F., Gomez E., Alcon A., Santos V.E., 2013. The effect of hydrodynamic stress on the growth of Xanthomonas campestris cultures in a stirred and sparged tank bioreactor. Bioprocess Biosyst. Eng., 36, 911925. DOI: 10.1007/s00449-012-0825-y.

Garcia-Ochoa F., Gomez E., Santos V.E., Merchuk J.C., 2010. Oxygen uptake rate in microbial processes: An overview. Biochem. Eng. J., 49, 289-307. DOI: 10.1016/j.bej.2010.01.011.

Gardeazabal T., Cabrera M., Cabrales P., Intaglietta M., Briceno J.C., 2008. Oxygen transport during hemodilution with a perfluorocarbon-based oxygen carrier: effect of altitude and hyperoxia. J. Appl. Physiol., 105, 588-594. DOI: 10.1152/japplphysiol.00152.2008.

Glazyrina J., Krause M., Junne S., Glauche F., Strom D., Neubauer P., 2012. Glucose-limited high cell density cultivations from small to pilot plant scale using an enzyme-controlled glucose delivery system. N. Biotechnol., 29, 235-242. DOI: 10.1016/j.nbt.2011.11.00.

Gomes L., Gomes E.R., 2007. Perfluorocarbons compounds used as oxygen carriers: from liquid ventilation to blood substitutes. Revista da Faculdade de Ciencias da Saude (University Fernando Pessoa, Portugal), 4, 5865.

Gogate P.R., Beenackers A.A.C.M., Pandit A.B., 2000. Multiple-impeller systems with a special emphasis on bioreactors: A critical review. Biochem. Eng. J., 6, 109-144. DOI: 10.1016/S1369-703X(00)00081-4.

Gotoh T., Michizuki G., Kikuchi K.-I., 2001a. Perfluorocarbon-mediated aeration applied to recombinant protein production by virus-infected insect cells. Biochem. Eng. J., 7, 69-78. DOI: 10.1016/S1369-703X(00)00103-0.

Gotoh T., Michizuki G., Kikuchi K.-I., 2001b. A novel column fermentor having a wetted-wall of perfluorocarbon as an oxygen carrier. Biochem. Eng. J., 8, 165-169. DOI: 10.1016/S1369-703X(01)00110-3.

Gruen D.W.R., 1985. A model for the chains in amphiphilic aggregates. 2. Thermodynamic and experimental comparisons for aggregates of different shape and size. J. Phys. Chem., 89, 153-163. DOI: $10.1021 / \mathrm{j} 100247 \mathrm{a} 033$. 
Grunzel P., Pilarek M., Steinbrück D., Neubauer A., Brand E., Kumke M.U., Neubauer P., Krause M., 2014. Mini-scale cultivation method enables expeditious plasmid production in Escherichia coli. Biotechnol. J., 9, 128-136. DOI: 10.1002/biot.201300177.

Hamamoto K., Tokashiki M., Ichikawa Y., Murakami H., 1987. High cell density culture of a hybridoma using perfluorocarbon to supply oxygen. Agric. Biol. Chem., 51, 3415-3416. DOI: 10.1271/bbb1961.51.3415.

Han B., Su T., Wu H., Gou Z., Xing X.-H., Jiang H., Chen Y., Li X., Murrell J.C., 2009. Paraffin oil as a "methane vector" for rapid and high cell density cultivation of Methylosinus trichosporium OB3b. Appl. Microbiol. Biotechnol., 83, 669-677. DOI: 10.1007/s00253-009-1866-2.

Hill S.E., Leone B.J., Faithfull N.S., Flaim K.E., Keipert P.E., Newman M.F., 2002. Perflubron emulsion (AF0144) augments harvesting of autologous blood: a phase II study in cardiac surgery. J. Cardiothorac. Vasc. Anesth., 16, 555-560. DOI: 10.1053/jcan.2002.126947.

Hillig F., Annemüller S., Chmielewska M., Pilarek M., Junne S., Neubauer P., 2013. Bioprocess development in single-use systems for heterotrophic marine microalgae. Chem. Ing. Tech., 85, 153-161. DOI: 10.1002/cite.201200143.

Hillig F., Pilarek M., Junne S., Neubauer P., 2014. Cultivation of marine microorganisms in single-use systems. Adv. Biochem. Eng. Biotechnol., 138, 179-206. DOI: 10.1007/10_2013_219.

Hondred P.R., Yoon S., Bowler N., Kessler M.R., 2013. Degradation kinetics of polytetrafluoroethylene and poly(ethylene-alt-tetrafluoroethylene). High Perform. Polym., 25, 535-542. DOI: 10.1177/0954008312473491.

Jewitt N., Anthony P., Lowe K.C., de Pomerai D.I., 1999. Oxygenated perfluorocarbon promotes nematode growth and stress-sensitivity in a two-phase liquid culture system. Enz. Microb. Technol., 25, 349-356. DOI: 10.1016/S0141-0229(99)00052-6.

Ju L.K., Lee J.F., Armiger W.B., 1991. Enhancing oxygen transfer in bioreactors by perfluorocarbon emulsions. Biotechnol. Prog., 7, 323-329. DOI: 10.1021/bp00010a006.

Kaisers U., Kelly K.P., Busch T., 2003. Liquid ventilation. Br. J. Anaesth., 91, 143-151. DOI: 10.1093/bja/aeg147.

Kaufman R.J., 1992. Perfluorochemical emulsions as blood substitutes, In: Sjöblom J. (Eds.), Emulsions - A fundamental and practical approach NATO ASI series. Springer Netherlands, 207-226. DOI: 10.1007/978-94011-2460-7_14.

Kaufmann B.A., Lindner J.R., 2007. Molecular imaging with targeted contrast ultrasound. Curr. Opin. Biotechnol., 18, 11-16. DOI: 10.1016/j.copbio.2007.01.004.

Kim H.W., 2007. Engineering blood cells and proteins as blood substitutes: a short review. Biotechnol. Bioproc. Eng., 12, 43-47. DOI: 10.1007/BF02931802.

Kirsch P., 2004. Modern fluoroorganic chemistry. Synthesis, reactivity, applications. Wiley-VCH Verlag, Weinheim.

Kołtuniewicz A.B., 2014. Sustainable process engineering. De Gruyter, Berlin, 354-356.

Kraft M.P., Riess J.G., 1998. Highly fluorinated amphiphiles and colloidal systems, and their applications in the biomedical field. A contribution. Biochimie, 80, 489-514. DOI: 10.1016/S0300-9084(00)80016-4.

Krafft M.P., Chittofrati A., Riess J.G., 2003. Emulsions and microemulsions with fluorocarbon phase. Curr. Opin. Colloid Interface. Sci., 8, 251-258. DOI: 10.1016/S1359-0294(03)00045-1.

Krafft M.P., Riess J.G., 2007. Perfluorocarbons: life sciences and biomedical uses. J. Polym. Sci. Part A: Polym. Chem., 45, 1185-1198. DOI: 10.1002/pola.21937.

Kuznetsova I.N., 2003. Perfluorocarbon emulsions: stability in vitro and in vivo (a review). Pharm. Chem. J., 37, 415-420. DOI: 10.1023/A:1027355913348.

Lai Z.-W., Rahim R.A., Ariff A.B., Mohamad R., 2012. Biosynthesis of high molecular weight hyaluronic acid by Streptococcus zooepidemicus using oxygen vector and optimum impeller tip speed. J. Biosci. Bioeng., 114, 286291. DOI: 10.1016/j.jbiosc.2012.04.011.

Lamy M., Deby-Dupont G., 2009. Current status of oxygen carriers. Sartoniana, 22, 113-130.

Lanza G. M., Wickline S. A., 2001. Targeted ultrasonic contrast agents for molecular imaging and therapy. Progr. Cardiovasc. Dis., 44, 13-31. DOI: 10.1053/pcad.2001.26440.

Lee Y.H., Yeh Y.L., Lin K.H., Hsu Y.C., 2013. Using fluorochemical as oxygen carrier to enhance the growth of marine microalga Nannochloropsis oculata. Bioprocess Biosyst. Eng., 36, 1071-1078. DOI: 10.1007/s00449012-0860-8.

Lewandowski G., Meissner E., Milchert E., 2006. Special applications of fluorinated organic compounds. J. Hazard. Mater., 136, 385-391. DOI: 10.1016/j.jhazmat.2006.04.017. 
Li M., Meng X., Diao E., Du F., Zhao X., 2012. Productivity enhancement of S-adenosylmethionine in Saccharomyces cerevisiae using n-hexadecane as oxygen vector. J. Chem. Technol. Biotechnol., 87, 1379-1384. DOI: 10.1002/jctb.3752.

Li H., Wijekoon A., Leipzig N.D., 2014. Ecapsulated neural differentiation in fluorinated methacrylamide chitosan hydrogels. Ann. Biomed. Eng., 42, 1456-1469. DOI: 10.1007/s10439-013-0925-0.

Lowe K.C., 1999. Perfluorinated blood substitutes and artificial oxygen carriers. Blood Rev., 171-184. DOI: 10.1054/blre.1999.0113.

Lowe K.C., 2001. Fluorinated blood substitutes and oxygen carriers. J. Fluor. Chem., 109, 59-65. DOI: 10.1016/S0022-1139(01)00374-8.

Lowe K.C., 2002. Perfluorochemical respiratory gas carriers: Benefits to cell culture systems. J. Fluor. Chem., 118, 19-26. DOI: 10.1016/S0022-1139(02)00200-2.

Lowe K.C., Anthony P., Power J.B., Davey M.R., 2003. Novel approaches for regulating gas supply to plant systems in vitro: Application and benefits of artificial gas carriers. In Vitro Cell. Dev. Biol. Plant, 39, 557-566. DOI: 10.1079/IVP2003469.

Lowe K.C., Anthony P., Davey M.R., Power J.B., 2001. Beneficial effects of Pluronic F-68 and artificial oxygen carriers on the post-thaw recovery of cryopreserved plant cells. In Vitro Cell. Dev. Biol. Anim., 29, 297-316. DOI: $10.1081 / \mathrm{BIO}-100104232$.

Maillard E., Sanchez-Dominguez M., Kleiss C., Langlois A., Sencier M.C., Vodouhe C., Beitigier W., Krafft M.P., Pinget M., Belcourt A., Sigrist S., 2008. Perfluorocarbons: new tool for islets preservation in vitro. Transplant. Proc., 40, 372-374. DOI: 10.1016/j.transproceed.2008.01.006.

Martin K.H., Dayton P.A., 2013. Current status and prospects for microbubbles in ultrasound theranostics. Wiley Interdiscip Rev Nanomed Nanobiotechnol., 5, 329-45. DOI: 10.1002/wnan.1219.

Martin M., Montes F.J., Galan M.A., 2010. Mass transfer rates from bubbles in stirred tanks operating with viscous fluids. Chem. Eng. Sci., 65, 3814-3824. DOI: 10.1016/j.ces.2010.03.015.

Martin S., Soucaille P., Condoret J.-S., 1995. Bubble free gaseous transfer in bioreactors using perfluorocarbons. Bioprocess Eng., 13, 293-300. DOI: 10.1007/BF00369560.

Martin Y., Vermette P., 2005. Bioreactors for tissue mass culture: design, characterization and recent advances. Biomaterials, 26, 7481-7503. DOI: 10.1016/j.biomaterials.2005.05.057.

Maevsky E., Ivanitsky G., 2005. Oxygen-dependent and oxygen-independent effects of Perftoran, In: Kobayashi K., Tsuchida E., Horinouchi H. (Eds.), Artificial Oxygen Carrier. Its Front Line. Springer Verlag, Tokyo, 221228. DOI: $10.1007 / 4-431-26651-8 \_17$.

Maevsky E., Ivanitsky G., Bogdanova L., Axenova O., Karmen N., Zhiburt E., Senina R., Pushkin S., Maslennikov I., Orlov A., Marinicheva I., 2005. Clinical results of Perftoran application: present and future. Artif. Cells Blood Substit. Immobil. Biotechnol., 33, 37-46. DOI: 10.1081/BIO-200046654.

Menge M., Mukherjee J., Scheper T., 2001. Application of oxygen vectors to Claviceps purpurea cultivation. Appl. Microbiol. Biotechnol., 55, 411-416. DOI: 10.1007/s002530100592.

Mitsuno T., Ohyanagi H., Naito R., 1982. Clinical studies of a perfluorochemical whole blood substitute (FluosolDA) Summary of 186 cases. Ann. Surg., 195, 60-69.

Neubauer P., Junne S., 2010. Scale-down simulators for metabolic analysis of large-scale bioprocesses. Curr. Opin. Biotechnol., 21, 114-121. DOI: 10.1016/j.copbio.2010.02.001.

Ntwampe S.K.O., Williams C.C., Sheldon M.S., 2010. Water-immiscible dissolved oxygen carriers in combination with Pluronic F 68 in bioreactors. Afr. J. Biotechnol., 9, 1106-1114.

Percheron G., Brechignac F., Soucaille P., Condoret J.-S., 1995. Carbon dioxide desorption from fermentation broth by use of oxygen vectors. Bioprocess Eng., 12, 11-16. DOI: 10.1007/BF01112987.

Pilarek M., Szewczyk K.W., 2005. Zastosowania perfluorozwiązków jako ciekłych nośników gazów oddechowych w medycynie i biotechnologii. Biotechnologia, 69, 125-150.

Pilarek M., Szewczyk K.W., 2007. Application of a liquid oxygen carrier in plant cell suspension cultures. $J$. Biotechnol., 131, Supplement, S143. DOI: 10.1016/j.jbiotec.2007.07.850.

Pilarek M., Szewczyk K.W., 2008. Effects of perfluorinated oxygen carrier application in yeast, fungi and plant cell suspension cultures. Biochem. Eng. J., 41, 38-42. DOI: 10.1016/j.bej.2008.03.004.

Pilarek M., Brand E., Hillig F., Krause M., Neubauer P., 2013a. Enhanced plasmid production in miniaturized high-cell-density cultures of Escherichia coli supported with perfluorinated oxygen carrier. Bioprocess Biosyst. Eng., 36, 1079-1086. DOI 10.1007/s00449-012-0861-7. 
Pilarek M., Dębowska J., Szewczyk K.W., 2009. Hodowla komórek Nicotiana tabacum BY-2 w bioreaktorze membranowym z wykorzystaniem perfluorowanego nośnika tlenu. Inż. Ap. Chem., 48, 85-86.

Pilarek M., Glazyrina J., Neubauer P., 2011. Enhanced growth and recombinant protein production of Escherichia coli by a perfluorinated oxygen carrier in miniaturized fed-batch cultures. Microb. Cell Fact., 10, 50. DOI: 10.1186/1475-2859-10-50.

Pilarek M., Grabowska I., 2012. Growth of animal cells on flexible interface of liquid fluorocarbon. Eng. Biomater., 114, 12-14.

Pilarek M., Grabowska I., Ciemerych M.A., Dąbkowska K., Szewczyk K.W., 2013b. Morphology and growth of mammalian cells in a liquid/liquid culture system supported with oxygenated perfluorodecalin. Biotechnol. Lett., 35, 1387-1394. DOI 10.1007/s10529-013-1218-2.

Pilarek M., Grabowska I., Senderek I., Wojasiński M., Janicka J., Janczyk-Ilach K., Ciach T., 2014. Liquid perfluorochemical-supported hybrid cell culture system for proliferation of chondrocytes on fibrous polylactide scaffolds. Bioprocess Biosyst. Eng., DOI: 10.1007/s00449-014-1143-3.

Pilarek M., Zygmuntowicz J., Dąbkowska K., Moniuk W., 2013c. Wykorzystanie metody enzymatycznej do badania rozpuszczalności tlenu w ciekłych perfluorowiązkach. Inż. Ap. Chem., 52, 467-468.

Pilarek M., Szewczyk K.W., Stępniewski J., Anderszewska A., 2006. Zastosowanie perfluorowanego nośnika tlenu w hodowlach mikroorganizmów. Przemyst Chemiczny, 85, 1131-1133.

PL Patent P-404726, 16.07.2013. Application of perfluorochemicals for plant metabolites in situ extraction.

Pohorecki R., Bałdyga J., Ryszczuk A., Motyl T., 2001. Erythrocyte destruction during turbulent mixing. Biochem. Eng. J., 9, 147-154. DOI: 10.1016/S1369-703X(01)00135-8.

Pohorecki R., Moniuk W., 1988. Kinetics of reaction between carbon dioxide and hydroxyl ions in aqueous electrolyte solutions. Chem. Eng. Sci., 43, 1677-1684. DOI: 10.1016/0009-2509(88)85159-5.

Radisic M., Park H., Chen F., Salazar-Lazzaro J.E., Wang Y., Dennis R., Langer R., Freed L.E., VunjakNovakovic G., 2006. Biomimetic approach to cardiac tissue engineering: oxygen carriers and channeled scaffolds. Tissue Eng., 12, 2077-2091. DOI: 10.1098/rstb.2007.2121.

Randsoe T., Hyldegaard O., 2009. Effect of oxygen breathing and perfluorocarbon emulsion treatment on air bubbles in adipose tissue during decompression sickness. J. Appl. Physiol., 107, 1857-1863. DOI: 10.1152/japplphysiol.00785.2009.

Rappaport C., Trujillo E.M., Soong L.-F., 1996. Novel oxygenation system supports multilayer growth of HeLa cells. BioTechniques, 21, 672-677.

Rappaport C., Rensch Y., Abbasi M. , Kempe M., Rocaboy C., Gładysz J., Trujillo E.M., 2002. New perfluorocarbon system for multilayer growth of anchorage-dependent mammalian cells. BioTechniques, 32, 142-151.

Rappaport C., 2003. Progress in concept and practice of growing anchorage-dependent mammalian cells in three dimension. In Vitro Cell. Dev. Biol. Anim., 39, 187-192. DOI: 10.1290/1543706X(2003)039<0187:RICAPO>2.0.CO;2.

Rémy B., Deby-Dupont G., D’Ans V., Ernest P., Lamy M., 1999. Substituts des globules rouges: emulsions de fluorocarbures et solutions d'hemoglobine. Ann. Fr. Anesth. Reanim., 18, 211-224. DOI: 10.1016/S07507658(99)90155-7.

Richardson G.F., Gardiner Y.T., McNiven M.A., 2002. Preservation of rainbow trout (Oncorhynchus mykiss) eyed eggs using a perfluorochemical as an oxygen carrier. Theriogenology, 58, 1283-1290. DOI: 10.1016/S0093-691X(02)00955-X.

Riess J.G., 2001. Oxygen carriers ("blood substitutes") - raison d'etre, chemistry and some physiology. Chem. Rev., 101, 2797-2919. DOI: 10.1021/cr970143c.

Riess J.G., 2002a. Fluorous micro- and nanophases with biomedical perspective. Tetrahedron, 58, 4113-4131. DOI: $10.1016 / \mathrm{S} 0040-4020(02) 00262-4$.

Riess J.G., 2002b. Blood substitutes and other potential biomedical applications of fluorinated colloids. J. Fluor. Chem., 114, 119-126. DOI: 10.1016/S0022-1139(02)00017-9.

Riess J.G., 2005. Understanding the fundamentals of perfluorocarbons and perfluorocarbon emulsions relevant to in vivo oxygen delivery. Artif. Cells Blood Substit. Immobil. Biotechnol., 33, 47-63. DOI: 10.1081/BIO200046659.

Riess J.G., 2006a. Perfluorocarbon-based oxygen delivery. Artif. Cells Blood Substit. Immobil. Biotechnol., 34, 567-80. DOI: 10.1080/10731190600973824.

Riess J.G., 2006b. Fluorous materials for biomedical uses, In: Gladysz J. A., Curran D. P., Horvath I. (Eds.), Handbook of fluorous chemistry. Wiley-VCH, 521-561. DOI: 10.1002/3527603905.ch13. 
Riess J.G., Krafft M.P., 2006. Fluorocarbon emulsions as in vivo oxygen delivery systems: Background and chemistry, In: Winslow R.M. (Eds.), Blood Substitutes. Elsevier Academic Press, 259-275. DOI: 10.1016/B978012759760-7/50000-7.

Rols J.L., Condoret J.S., Fonade C., Goma G., 1990. Mechanism of enhanced oxygen transfer in fermentation using emulsified oxygen-vectors. Biotechnol. Bioeng., 35, 427-435. DOI: 10.1002/bit.260350410.

Ruiz-Cabello J., Barnett B.P., Bottomley P.A., Bulte J.W.M., 2011. Fluorine $\left({ }^{19} \mathrm{~F}\right) \mathrm{MRS}$ and MRI in biomedicine. NMR Biomed., 24, 114-129. DOI:10.1002/nbm.1570.

Ruland O., Spiegel H.U., Hauss J., Schönleben K., 1987. Oxypherol - a new way to preserve organs?, In: Ehrly A.M., Hauss J., Huch R. (Eds.), Clinical oxygen pressure measurement. Tissue oxygen pressure and transcutaneous oxygen pressure. Springer Verlag, Berlin Heidelberg. DOI: 10.1007/978-3-642-71226-5_30.

Sandford G., 2003. Perfluoroalkanes. Tetrahedron, 59, 437-454. DOI: 10.1016/S0040-4020(02)01568-5.

Shi Y., Sardonini C.A., Goffe R.A., 1998. The use of oxygen carriers for increasing the production of monoclonal antibodies from hollow fibre bioreactors. Res. Immunol., 149, 576-587. DOI: 10.1016/S0923-2494(98)80009-6.

Shiba Y., Ohshima T., Sato M., 1998. Growth and morphology of anchorage-dependent animal cells in a liquid/liquid interface system. Biotechnol. Bioeng., 57, 583-589. DOI: 10.1002/(SICI)10970290(19980305)57:5<583::AID-BIT10>3.0.CO;2-D.

Shine K.P., Gohar L.K., Hurley M.D., Marston G., Martin D., Simmonds P.G., Wallington T.J., Watkins M., 2005. Perfluorodecalin: Global warming potential and first detection in the atmosphere. Atmos. Environ., 39, 1759-1763. DOI: 10.1016/j.atmosenv.2005.01.001.

da Silva T.L., Calado V., Silva N., Mendes R.L., Alves S.S., Vasconcelos J.M.T., Reis A., 2006. Effects of hydrocarbon additions on gas-liquid mass transfer coefficients in biphasic bioreactors. Biotechnol. Bioprocess Eng., 11, 245-250. DOI: 10.1007/BF02932038.

Smoła M., Vandamme T., Sokołowski A., 2008. Nanocarriers as pulmonary drug delivery systems to treat and to diagnose respiratory and non respiratory diseases. Int. J. Nanomedicine, 3, 1-19. DOI: 10.2147/IJN.S1045.

Sobieszuk P., Pilarek M., 2012. Absorption of $\mathrm{CO}_{2}$ into perfluorinated gas carrier in the Taylor gas-liquid flow in a microchannel system. Chem. Process Eng., 33, 595-602. DOI: 12.2478/v10176-012-0049-3.

Spiess B.D., 2009. Perfluorocarbon emulsions as a promising technology: a review of tissue and vascular gas dynamics. J. Appl. Physiol., 106, 1444-1452. DOI: 10.1152/japplphysiol.90995.2008.

Suresh S., Srivastava V.C., Mishra I.M., 2009. Techniques for oxygen transfer measurement in bioreactors: A review. J. Chem. Technol. Biotechnol., 84, 1091-1103. DOI: 10.1002/jctb.2154.

Sykłowska-Baranek K., Pilarek M., Cichosz M., Pietrosiuk A., 2014. Liquid perfluorodecalin application for in situ extraction and enhanced naphthoquinones production in Arnebia euchroma cell suspension cultures. Appl. Biochem. Biotechnol., 172, 2618-2627. DOI 10.1007/s12010-013-0701-5.

Tawfic Q.A., Kausalya R., 2011. Liquid ventilation. Oman Med. J., 26, 4-9. DOI: 10.5001/omj.2011.02.

Terai S., Tsujimura T., Li S., Hori Y., Toyama H., Shinzeki M., Matsumoto I., Kuroda Y., Ku Y., 2010. Effect of oxygenated perfluorocarbon on isolated islets during transportation. J. Surg. Res., 162, 284-289. DOI: 10.1016/j.jss.2009.03.082.

Turick C.E., Bulmer D.K., Enhanced reduction of nitrous oxide by Pseudomonas denitrificans with perfluorocarbons. Biotechnol. Lett., 20, 123-125. DOI: 10.1023/A:1005364121431.

US Patent 4105798, 08.08.1978. Perfluoro polycyclic compounds for use as synthetic blood and perfusion media.

US Patent 5463082, 31.10.1995. Fluorous multiphase systems.

US Patent 5531219, 02.07.1996. Use of liquid fluorocarbons to facilitate pulmonary drug delivery.

US Patent 5702949, 30.12.1997. Culture method for multilayer growth of anchorage-dependent cells.

US Patent 6897331, 24.05.2005. Fluorous triphase and other multiphase systems.

US Patent 7404943, 29.07.2008. Methods for solubilizing and recovering fluorinated compounds.

US Patent 20060278224, 22.03.2011. Process for transient and steady state delivery of biological agents to the lung via breathable liquids.

Vasquez D.M., Ortiz D., Alvarez O.A., Briceno J.C., Cabrales P., 2013. Hemorheological implications of perfluorocarbon based oxygen carrier interaction with colloid plasma expanders and blood. Biotechnol. Prog., 29, 796-807. DOI: 10.1002/btpr.1724.

Wardrop J., Lowe K.C., Power J.B., Davey M.R., 1996. Perfluorochemicals and plant biotechnology: an improved protocol for protoplast culture and plant regeneration in rice (Oryza sativa L.). J. Biotechnol., 50, 4754. DOI: 10.1016/0168-1656(96)01548-9. 
Wasanasathian A., Peng C.A., 2001. Enhancement of microalgal growth by using perfluorocarbon as oxygen carrier. Artif. Cells Blood Substit. Immobil. Biotechnol., 29, 47-55. DOI: 10.1081/BIO-100001255.

Wesseler E.P., Iltis R., Clark L.C., 1977. The solubility of oxygen in highly fluorinated liquids. J. Fluorine Chem., 9, 137-146. DOI: 10.1016/S0022-1139(00)82152-1.

Wijekoon A., Fountas-Davis N., Leipzig N.D., 2013. Fluorinated methacrylamide chitosan hydrogel systems as adaptable oxygen carriers for wound healing. Acta Biomater., 9, 5653-5664. DOI: 10.1016/j.actbio.2012.10.034.

Yacoub A., Hajec M.C., Stanger R., Wan W., Young H., Mathern B.E., 2014. Neuroprotective effects of perflurocarbon (oxycyte) after contusive spinal cord injury. J. Neurotrauma, 31, 256-267. DOI: 10.1089/neu.2013.3037.

Yue J., Chen G., Yuan Q., Luo L., Gonthier Y., 2007. Hydrodynamics and mass transfer characteristics in gasliquid flow through a rectangular microchannel. Chem. Eng. Sci., 62, 2096-2108. DOI: 10.1016/j.ces.2006.12.057.

Zetterlund P.B., Kagawa Y., Okubo M., 2008. Controlled/living radical polymerization in dispersed systems. Chem. Rev., 108, 3747-3794. DOI: 10.1021/cr800242x.

Zhu M.M., Goyal A., Rank D.L., Gupta S.K., Vanden Boom T., Lee S.S., 2005. Effects of elevated $\mathrm{pCO}_{2}$ and osmolarity on growth of $\mathrm{CHO}$ cells and production of antibody-fusion protein B1: A case study. Biotechnol. Prog., 21, 70-77. DOI: 10.1021/bp049815s.

Received 21 August 2014

Received in revised form 07 October 2014

Accepted 08 October 2014 